Prawne i ekonomiczne aspekty migracji, red. Magdalena Butrymowicz, Piotr Kroczek,

Kraków 2016, s. 85-128 (Biblioteczka Prawa, 1).

DOI: http://dx.doi.org/10.15633/9788374385473.06

Bartosz Kucia

UNIWERSYTET ŚLĄSKI W KATOWICACH

\title{
Ograniczenia swobody testowania ze względu na ochronę interesów osób bliskich. Uwagi na tle wybranych systemów common law
}

W systemach prawnych, w których akceptuje się ideę własności prywatnej, powszechnie przyznaje się spadkodawcy prawo do zadysponowania majątkiem na wypadek śmierci. Może on wówczas wedle własnego uznania ułożyć porządek dziedziczenia po sobie.

Zazwyczaj jednak testator nie ma nieskrępowanej swobody testowania. Zagadnienie zakresu tej swobody ma podstawowe znaczenie dla prawa spadkowego. W jego ramach należy zwłaszcza udzielić odpowiedzi na pytanie, czy testator ma obowiązek dokonania odpowiednich rozrządzeń testamentowych na rzecz określonych osób (np. małżonka, krewnych, przysposobionych, osób, z którymi pozostawał w faktycznym pożyciu czy też na których utrzymanie łożył).

W poszczególnych porządkach prawnych poziom ochrony wspomnianych osób jest zróżnicowany, zarówno pod względem podmiotowym, jak również w zakresie charakteru prawnego i treści przyznawanych 
uprawnień. W konsekwencji sprawą istotną jest ustalenie prawa właściwego, które znajdzie zastosowanie do oceny omawianego zagadnienia. Na aktualność tego tematu wpływa zwłaszcza zauważalny w ostatnich latach wzrost emigracji Polaków do państw, w których obowiązuje system prawa precedensowego (tzw. common law) ${ }^{1}$. Emigracja skutkuje bowiem nie tylko konsekwencjami osobistymi czy społecznymi, lecz także określonymi skutkami prawnymi.

Przeniesienie miejsca zamieszkania do kraju common law może (i często będzie) skutkować tym, że ograniczenia swobody testowania będą podlegały ocenie według prawa kraju osiedlenia zmarłego emigranta $^{2}$. W celu ustalenia prawa właściwego sąd kraju osiedlenia stosuje bowiem przede wszystkim własne prawo prywatne międzynarodowe ${ }^{3}$.

1 W szczególności do Zjednoczonego Królestwa Wielkiej Brytanii i Irlandii Północnej, Irlandii, Stanów Zjednoczonych Ameryki, Kanady, Australii, Nowej Zelandii. Systemy prawne Quebecu i Luizjany, ze względu na historyczny wpływ wzorców prawa francuskiego, należą natomiast do tzw. systemów mieszanych. Podobnie w przypadku prawa szkockiego, w którym współistnieją elementy charakterystyczne dla prawa precedensowego i kontynentalnego. Por. np. A. Eccles, Scotland, [w: International succession, ed. L. Garb, J. Wood, Oxford 2010, s. 621. Zakresem niniejszej pracy objęto wymienione porządki prawne common law i prawo szkockie.

2 Ze względu na przedmiot niniejszej pracy dalsze uwagi kolizyjne ograniczono do kwestii prawa właściwego dla oceny ograniczeń swobody testowania związanych z ochroną bliskich testatora.

3 W krajach common law stosowaniu własnego prawa materialnego sprzyjają zresztą charakterystyczne zasady proceduralne, wedle których sąd stosuje z urzędu prawo rodzime; prawo obce zaś jedynie na żądanie strony, na której spoczywa dodatkowo obowiązek wykazania treści tego prawa. Jest to konsekwencją przyjęcia, że treść prawa obcego należy do zakresu okoliczności faktycznych, które powinna powołać strona postępowania (tzw. matter of fact). Por. np. J. H. C. Morris, D. McClean, The conflict of laws, London 2000, s. 10-16; J. J. Fawcett, J. M. Carruthers, P. North, Cheshire, North \& Fawcett private international law, Oxford 2008, s. 111-113 (na tle prawa angielskiego); E. B. Crawford, J. M. Carruthers, International private law in Scotland, Edinburgh 2006, s. 46 (prawo szkockie); J. Walker, Halsbury's laws of Canada, Markham 2011, s. 519n (prawo kanadyjskie); M. Davies, A. Bell, P. Le Gay Brereton, Nygh's conflict of laws in Australia, 
W omawianych porządkach common law rozwiązaniem typowym jest objęcie kwestii ograniczeń swobody testowania zakresem prawa właściwego dla tzw. ważności materialnej testamentu. Jest nim w odniesieniu do ruchomości (movables) prawo państwa domicylu spadkodawcy z chwili jego śmierci (lex domicilii) ${ }^{4}$, zaś w przypadku nieruchomości (immovables) ${ }^{5}$ - prawo państwa położenia nieruchomości (tzw. lex loci rei sitae $)^{6}$.

Chatswood 2014, s. 402n (prawo australijskie). Podobnie w prawie amerykańskim, choć na wzór aktów modelowych Uniform Judicial Notice of Foreign Law Act 1936 i Uniform Interstate and International Procedure Act 1962 prawodawcy licznych stanów USA wprowadzili odstępstwa od wspomnianych zasad w kierunku przyznania sądom kompetencji do prowadzenia $\mathrm{z}$ urzędu postępowania dowodowego co do treści prawa obcego, w razie gdyby strona wniosła o rozpoznanie sprawy wedle tego prawa. Nie zwalnia to jednak na ogół strony od obowiązku przedstawienia dowodów co do treści tego prawa. Por. szerzej, w tym na temat wspomnianych aktów modelowych: E. F. Scoles et al., Conflict of laws, St. Paul 2004, s. 543-556; D. P. Currie et al., Conflict of laws. Cases - comments - questions, St. Paul 2006, s. 87n; R. J. Weintraub, Commentary on the conflict of laws, New York 2006, s. 112n.

4 W angielskiej ustawie poświęconej ochronie osób bliskich spadkodawcy do przesłanek roszczenia zalicza się posiadanie przez spadkodawcę w chwili śmierci domicylu w Anglii lub Walii. Tak: $\$ 1(1)$ Inheritance (Provision for Family and Dependants) Act 1975 c. 63 ze zm., obowiązującego w Anglii i Walii. W razie braku spełnienia tej przesłanki sąd odmówi uwzględnienia roszczenia. Zob. np. Agulian vs Cyganik [2006] EwCA Civ 129. Por. także C. Sawyer, M. Spero, Succession, wills and probate, Abingdon 2015, s. 323. Rozwiązanie to spotkało się z słuszną krytyką doktrynalną, ponieważ wyłącza roszczenie także wówczas, gdy sąd angielski ustali właściwość jego prawa rodzimego wyłącznie w odniesieniu do nieruchomości (lex loci rei sitae). Zob. J. J. Fawcett, J. M. Carruthers, P. North, Cheshire..., dz. cyt., s. 128o. Zob. również w prawie północnoirlandzkim: $\$ 3(1)$ Inheritance (Provision for Family and Dependants) (Northern Ireland) Order 1979 No. 924 (N.I. 8) ze zm.

5 Na tle prawa kolizyjnego pojęć movables i immovables nie utożsamia się z konstrukcjami przyjętymi w krajowym prawie rzeczowym. Por. szerzej np. J. H. C. Morris, D. McClean, The conflict..., dz. cyt., s. 379n; J. Walker, Halsbury's..., dz. cyt., s. 817n; E. B. Crawford, J. M. Carruthers, International..., dz. cyt., s. 505n; M. Davies, A. Bell, P. Le Gay Brereton, Nygh's..., s. $727 \mathrm{n}$.

6 Tak np. w prawie angielskim (J. H. C. Morris, D. McClean, The conflict..., dz. cyt., s. 432-435; J. J. Fawcett, J. M. Carruthers, P. North, Cheshire..., dz. cyt., s. 1270, 
W związku z wejściem w życie unijnego rozporządzenia spadkowego $\mathrm{nr}$ 650/2012 z dnia 4 lipca 2012 roku $^{7}$ sądy polskie mogą częściej stawać przed koniecznością stosowania w odnośnej kwestii praw spadkowych krajów common law, w których osiedlili się obywatele

1279), szkockim (w którym orzecznictwo uzupełnia łącznik miejsca położenia nieruchomości subokreślnikiem temporalnym chwili śmierci spadkodawcy; por. E. B. Crawford, J. M. Carruthers, International..., s. 549-550, 560); kanadyjskim (J. Walker, Halsbury's..., dz. cyt., s. 886n), australijskim (M. Davies, A. Bell, P. Le Gay Brereton, Nygh's..., dz. cyt., s. 861n; G. E. Dal Pont, K. F. Mackie, Law of succession, Chatswood 2013, s. 716), amerykańskim (choć czasem przysługujące bliskim testatora tzw. allowances kwalifikuje się jako kwestię objętą zakresem tzw. administracji spadku; por. E. F. Scoles et al., Conflict of laws, dz. cyt., s. 1128, 1133-1136). Por. także przyp. 124. Szerzej na temat tzw. administracji spadkiem zob. np. M. Pazdan, Zasięg jurysdykcji krajowej w sprawach spadkowych, „Studia Cywilistyczne” 20 (1972), s. 128-129; M. Pazdan, Kolizyjnoprawna problematyka nabycia spadku, „Studia Cywilistyczne” 23 (1974), s. 134n; A. Kozioł, System administracji spadku w porzadkach prawnych państw kręgu anglosaskiego, „Rejent” (2006) nr 2, s. 119-132; B. Kucia, Dokumentowanie praw do spadku w prawie angielskim, [w:] Akty poświadczenia dziedziczenia na tle harmonizacji prawa prywatnego, red. E. Rott-Pietrzyk, A. Strzebińczyk, Bielsko-Biała 2015, s. 8-16.

7 Rozporządzenie Parlamentu Europejskiego i Rady (UE) nr 650/2012 z dnia 4 lipca 2012 r. w sprawie jurysdykcji, prawa właściwego, uznawania i wykonywania orzeczeń, przyjmowania i wykonywania dokumentów urzędowych dotyczących dziedziczenia oraz w sprawie ustanowienia europejskiego poświadczenia spadkowego (Dz.U. UE L 201 z 27 lipca 2012 r., s. 107 ze zm.) stosuje się do dziedziczenia po osobach zmarłych w dniu lub po dniu 17 sierpnia 2015 roku. Por. szerzej art. 83 rozporządzenia. Rozporządzenie nie obowiązuje obecnie w Zjednoczonym Królestwie, Irlandii i Danii (por. pkt. 82 i 83 preambuły rozporządzenia), które na potrzeby rozporządzenia należy traktować jako państwa trzecie, nie zaś państwa członkowskie Unii Europejskiej. Por. A. Wysocka-Bar, Prawo właściwe dla dziedziczenia według unijnego rozporządzenia dotyczącego spraw spadkowych, „Kwartalnik Prawa Prywatnego” (2012) z. 4, s. 916; M. Pazdan, Zakres zastosowania rozporządzenia spadkowego, [w:] Nowe europejskie prawo spadkowe, red. M. Pazdan, J. Górecki, Warszawa 2015, s. 31; K. Weitz, Jurysdykcja krajowa w sprawach spadkowych $w$ świetle rozporządzenia spadkowego, [w:] Nowe europejskie prawo spadkowe, dz. cyt., s. 56, przyp. 75 . 
polscy $^{8}$. W myśl tego rozporządzenia ograniczenia swobody testowania podlegają prawu właściwemu dla ogółu spraw dotyczących spadku (art. 23 ust. 1 pkt h rozporządzenia). Zasadniczo prawem tym jest zaś prawo państwa, w którym zmarły miał miejsce zwykłego pobytu $\mathrm{w}$ chwili jego śmierci ${ }^{9}$ (art. 21 ust. 1 rozporządzenia) ${ }^{10}$. Przyjęcie tego

8 W świetle rozporządzenia unijnego jurysdykcję sądów polskich w takim przypadku pozwala uzasadnić art. 10, który odnosi się do spraw po spadkodawcach, którzy w chwili śmierci mieli miejsce zwykłego pobytu poza państwami członkowskimi Unii Europejskiej, w tym również, wobec nieobowiązywania w nich rozporządzenia, w Zjednoczonym Królestwie, Irlandii lub Danii. Por. poprzedni przypis. Sądy państwa członkowskiego, w którym znajdują się składniki majątku spadkowego, pomimo tego mają jurysdykcję do orzekania co do ogółu spraw spadkowych, jeżeli zmarły w chwili śmierci miał obywatelstwo tego państwa członkowskiego albo nie był wprawdzie obywatelem, lecz miał wcześniej miejsce zwykłego pobytu w tym państwie członkowskim, a do chwili wniesienia sprawy do sądu upłynęło nie więcej niż pięć lat od chwili zmiany tego miejsca zwykłego pobytu (art. 10 ust. 1 rozporządzenia). W braku jurysdykcji zgodnie $\mathrm{z}$ art. 10 ust. 1 sąd państwa członkowskiego ma jurysdykcję do orzekania w sprawach dotyczących składników majątku spadkowego, które w tym państwie się znajdują (art. 10 ust. 2 rozporządzenia).

9 Nie należy utożsamiać pojęć: miejsca zwykłego pobytu (habitual residence) i miejsca zamieszkania (domicile), które, choć zbliżone, różnią się intensywnością więzi z państwem pobytu. Por. M. Pazdan, Prawo prywatne międzynarodowe, Warszawa 2008, s. 54-55. Domicyl od zwykłego pobytu (ordinary, habitual residence) odróżnia się również w prawie kolizyjnym common law, nadając temu pierwszemu pojęciu szczególną treść, w ramach której istotną rolę odgrywa zamiar stałego zamieszkiwania w danym państwie bez ograniczeń czasowych. Por. np. J. J. Fawcett, J. M. Carruthers, P. North, Cheshire..., dz. cyt., s. 153n; J. H. C. Morris, D. McClean, The Conflict..., dz. cyt., s. 19n; A. Wysocka-Bar, Wybór prawa w międzynarodowym prawie spadkowym, Warszawa 2013, s. 54.

10 Łącznik miejsca zwykłego pobytu nawiązuje do kryteriów faktycznych, a nie prawnych (jak np. łącznik obywatelstwa), co może być źródłem problemów praktycznych z jego zastosowaniem. Nie zmienia to jednak ogólnej, pozytywnej oceny tego rozwiązania. Pozwala ono bowiem na rozstrzygnięcie sprawy spadkowej wedle prawa państwa, z którym obywatel polski jest ściśle związany, ponieważ zwykle tam przebywa, co niejednokrotnie wiąże się z uzyskaniem tamże stałego zatrudnienia, majątku czy założeniem rodziny. Por. także m.in. M. Pazdan, Statut spadkowy w świetle rozporządzenia spadkowego, [w:] Nowe 
łącznika stanowi odejście od dotychczasowej normy kolizyjnej prawa polskiego, wedle której do oceny sprawy spadkowej po zmarłym obywatelu polskim (w tym również ograniczeń swobody testowania) sąd polski powinien stosować prawo polskie, bez względu na miejsce zamieszkania lub pobytu spadkodawcy (właściwość legis patriae), chyba że spadkodawca dokonał wyboru innego prawa przez poddanie sprawy spadkowej swojemu prawu ojczystemu, prawu miejsca swojego zamieszkania albo prawu miejsca swojego zwykłego pobytu z chwili dokonania wyboru lub z chwili swojej śmierci (art. 64 ustawy z dnia 4 lutego 2011 r. o prawie prywatnym międzynarodowym) ${ }^{11}$. Zatem rozporządzenie unijne jeszcze bardziej niż dotychczasowa ustawa polska sprzyja powstawaniu sytuacji, w których polskie sądy będą orzekały wedle unormowań spadkowych krajów common law w sprawach obywateli polskich, którzy osiedlili się w tychże krajach ${ }^{12}$.

europejskie prawo spadkowe, dz. cyt., s. 97n. Wyjątkowo, gdy z wszystkich okoliczności sprawy jasno wynika, że w chwili śmierci zmarły był w sposób oczywisty bliżej związany z państwem innym niż państwo jego miejsca zwykłego pobytu w chwili śmierci, prawem właściwym dla dziedziczenia jest prawo tego innego państwa (art. 21 ust. 2 rozporządzenia). Rozporządzenie umożliwia ponadto przyszłemu spadkodawcy dokonanie wyboru jako prawa właściwego prawa państwa, którego obywatelstwo ma w chwili dokonywania wyboru lub chwili śmierci (art. 22 rozporządzenia).

11 Artykuł 64 Ustawy z dnia 4 lutego 2011 r. Prawo prywatne międzynarodowe (Dz.U. Z 2011 r., Nr 80, poz. 432 ze zm.) został uchylony 17 sierpnia 2015 roku na mocy Ustawy z dnia 24 lipca 2015 r. o zmianie ustawy - Kodeks postępowania cywilnego, ustawy Prawo o notariacie oraz niektórych innych ustaw (Dz.U. z 2015 r., poz. 1137). Możliwości wyboru prawa właściwego nie dopuszczono natomiast w art. 34 Ustawy z dnia 12 listopada 1965. Prawo prywatne międzynarodowe (Dz.U. z 1965 r., Nr 46, poz. 290 ze zm.), w którym posłużono się jedynie łącznikiem obywatelstwa spadkodawcy z chwili jego śmierci. Zakres prawa właściwego wskazywanego przez podane przepisy (statutu spadkowego) obejmował również ograniczenia swobody testowania. Por. M. Pazdan, Prawo prywatne międzynarodowe, dz. cyt., s. 298; A. Wysocka-Bar, Wybór prawa..., dz. cyt., s. 298.

Ograniczeniu liczby spraw tego rodzaju służy art. 10 rozporządzenia, który uzależnia jurysdykcję sądu polskiego od położenia składników majątku 
Wskazanie prawa danego kraju common law jako właściwego na podstawie art. 21 ust. 1 rozporządzenia nie zawsze jednak obliguje sąd polski do stosowania właśnie tego prawa. Odmienność łączników przyjętych w rozporządzeniu unijnym (miejsca zwykłego pobytu) i w systemach common law (domicylu, miejsca położenia nieruchomości) sprzyja bowiem stosowaniu odesłania ${ }^{13}$.

Nie zmienia to jednak faktu, że już sama tylko zmiana miejsca zamieszkania spadkodawcy, nawet bez zerwania formalnej więzi obywatelstwa państwa dotychczas zamieszkiwanego, może istotnie wpłynąć na zakres swobody testowania, $\mathrm{w}$ tym również przez wzmocnienie lub osłabienie sytuacji osób bliskich testatora.

spadkowego w Polsce. Por. przyp. 8. Nierzadko jednak polscy emigranci pozostawią w Polsce niektóre składniki swojego majątku, co uzasadni jurysdykcję sądu polskiego.

$13 \mathrm{~W}$ omawianym zakresie odesłanie wchodzi w rachubę, gdy normy kolizyjne prawa państwa trzeciego, wskazanego jako właściwe na podstawie art. 21 ust. 1 rozporządzenia, nie przewidują właściwości prawa własnego, lecz odsyłają do prawa obcego. W przypadku gdy prawem wskazanym, o którym mowa, jest prawo danego kraju common law (np. prawo Australii Zachodniej), dojdzie do odesłania przez normy kolizyjne tego prawa, gdy zwykły pobyt spadkodawcy w tym kraju nie spełnia przesłanek domicylu lub też gdy nieruchomość spadkowa jest położona poza granicami tego kraju (odesłanie nie dotyczy jednak wówczas nieruchomości położonych w tym kraju). W razie odesłania do prawa państwa członkowskiego w rozumieniu rozporządzenia (np. polskiego) sąd polski stosuje prawo państwa, do którego odesłano. Tak jest również w przypadku odesłania do prawa państwa trzeciego (np. nowozelandzkiego), lecz tylko wtedy, gdy przewidują to jego normy kolizyjne (tzw. odesłanie dalsze przyjęte); w przeciwnym wypadku sąd polski stosuje prawo państwa wskazane jako właściwe na podstawie art. 21 ust. 1 rozporządzenia (a więc w omawianym przypadku prawo danego kraju common law). Rozporządzenie nie przewiduje natomiast odesłania w przypadku, gdy prawem właściwym wskazanym na podstawie art. 21 ust. 1 rozporządzenia jest prawo państwa członkowskiego. Por. art. 34 ust. 1 i 2 rozporządzenia. Por. szerzej M. Pazdan, Statut..., s. 105-106. W kwestii zaliczenia Zjednoczonego Królestwa, Irlandii i Danii do państw trzecich w rozumieniu rozporządzenia por. przyp. 7. 
Pożądana jest zatem analiza unormowań poświęconych ochronie osób bliskich spadkodawcy przed pozbawieniem korzyści ze spadku, które obowiązują w wybranych krajach common law. Regulacje tego rodzaju spotyka się w odnośnych porządkach powszechnie, choć niejednokrotnie cechuje je znaczna różnorodność, wynikająca z przyjętych założeń aksjologicznych co do znaczenia, jakie należy nadać zasadzie swobody testowania, jak i przyjętej koncepcji rodziny. Analizę zagadnienia należy wszakże przeprowadzić na dwóch płaszczyznach: po pierwsze katalogu osób uprawnionych, po drugie - charakteru prawnego i treści przysługujących im uprawnień. Sam tylko wąski katalog osób chronionych nie świadczy bowiem jeszcze o nieznacznych więzach nałożonych na swobodę testowania, którą wszakże może istotnie ograniczać obszerny zakres przyznanych uprawnień. Prawidłowość ta może działać również na odwrót.

\section{Zakres podmiotowy unormowań ochronnych}

Systemy common law wykazują znaczne zróżnicowanie w zakresie rozwiązań dotyczących podmiotowego zakresu unormowań ochronnych, począwszy od formułowania wąskich katalogów podmiotów uprawnionych, a skończywszy na wyliczeniach szczególnie rozbudowanych.

$\mathrm{Na}$ zakres ten wpływają aprobowane w danym państwie stosunki prawa rodzinnego, do których unormowania te bez wyjątku nawiązują. Wśród nich spotyka się zarówno instytucje nieznane polskiemu prawu merytorycznemu (związki partnerskie), jak również przez nie w sposób kompleksowy nienormowane (konkubinat). Warto wszakże zaznaczyć, że - podobnie zresztą jak w prawie polskim (art. 991 k.c.) - prawodawcy krajów common law przyznają uprawnienia ochronne jedynie wybranym członkom rodziny spadkodawcy. Przeciwnie jednak do polskiej instytucji zachowku, w systemach common law nie zawsze ogranicza się zakres przepisów ochronnych do osób 
złączonych więzami rodzinnymi. W stosunkowo licznych uregulowaniach o zaliczeniu do kręgu uprawnionych decydują inne względy, jak choćby obowiązki moralne spadkodawcy względem uprawnionego lub łączące ich relacje osobiste. Względy te są jednak obecne przede wszystkim w tych unormowaniach, w których krąg uprawnionych ukształtowano szeroko; katalogi wąskie ograniczają się najczęściej do kryteriów prawnorodzinnych.

W niektórych systemach common law wąsko zakreśla się krąg osób podlegających ochronie przed pozbawieniem korzyści ze spadku. Jest to rozwiązanie charakterystyczne zwłaszcza dla prawa amerykańskiego $^{14}$. Prawa spadkowe zdecydowanej większości stanów usa przyznają określone uprawnienia małżonkowi spadkodawcy; w znacznie ograniczonym zakresie zaś ochronie podlegają dzieci spadkodawcy ${ }^{15}$. Podobnie katalog osób uprawnionych ukształtowano w przepisach niektórych prowincji i terytoriów kanadyjskich ${ }^{16}$. Prawo szkockie chroni natomiast małżonka i zstępnych spadkodawcy ${ }^{17}$.

14 Zwrot „prawo amerykańskie” jest niezbędnym uproszczeniem. System prawny obowiązujący w Stanach Zjednoczonych Ameryki nie stanowi bowiem monolitu, zaś poszczególne stany usa i Dystrykt Kolumbii mają własne unormowania prawa spadkowego. Podobnie można mówić o prawie australijskim i kanadyjskim. Określenie "prawo angielskie” odnosi się natomiast w niniejszej pracy do prawa obowiązującego w Anglii i Walii, które mają wspólny system prawny. W każdej z pozostałych części Zjednoczonego Królestwa Wielkiej Brytanii i Irlandii Północnej obowiązują odrębne unormowania prawa spadkowego. Zob. także np. J. Wood, England and Wales, [w:] International succession, dz. cyt., s. 229.

15 Zob. także np. E. F. Scoles et al., Conflict of laws, s. 1133; E. Clark et al., Cases and materials on gratuitous transfers, St. Paul 2007, s. 133-135.

16 Unormowania Nowej Szkocji ( $\$ \$ 2$ (b) i 3(1) Testators' Family Maintenance Act, R.S.N.S. 1989 c. 465 [dalej: Ns Act 1989]) i Nowej Fundlandii i Labradoru (\$2 Family Relief Act, R.S.N.L. 1990 c. F-3 ze zm. [dalej: NL Act 1990] przyznają określone uprawnienia małżonkowi i dzieciom spadkodawcy.

$17 \mathrm{~W}$ omawianej materii na równi z małżonkiem traktuje się partnera pozostającego w związku partnerskim ze spadkodawcą (civil partner). Por. $\$ 131$ oraz 
Jednakże w licznych systemach common law można spotkać tendencję przeciwną (np. w prawie angielskim ${ }^{18}$, północnoirlandzkim ${ }^{19}$, kanadyjskim $^{20}$, australijskim ${ }^{21}$, nowozelandzkim ${ }^{22}$ ). Nie bez znaczenia są tu zmiany legislacyjne $z$ ostatnich dwudziestu lat, ukierunkowane na poszerzenie personalnego zakresu przepisów ochronnych.

Jeden z najszerszych katalogów osób uprawnionych przewiduje prawo angielskie w Inheritance (Provision for Family and Dependants) Act $1975^{23}$. Wśród osób uprawnionych prawo to wymienia: małżonków, partnerów w związkach partnerskich, także po rozwiązaniu albo unieważnieniu odpowiednio związku małżeńskiego lub partnerskiego, osoby pozostające w faktycznym pożyciu małżeńskim lub partnerskim

schedule 28 part 1 Civil Partnership Act 2004 c. 33 ze zm.; \$\$ 11 i 36(1) Succession (Scotland) Act 1964 c. 41 ze zm. [dalej: sct Act 1964] oraz common law. Por. także H. Hiram, The scots law of succession, Edinburgh 2010, s. 101; G. L. Gretton, A. J. M. Steven, Property, trusts and succession, Haywards Heath 2011, s. 385. Na skutek rekomendacji szkockiej komisji prawnej w ostatnim czasie prowadzone są prace legislacyjne nad rozszerzeniem kręgu uprawnionych o konkubentów. Zob. Scottish Law Commission, Report no. 215 on Succession, Edinburgh 2009, s. 6-7 i 66-76; The Scottish Government, Consultation on the law of succession, Edinburgh 2015, s. 46-47.

18 Tak: Inheritance (Provision for Family and Dependants) Act 1975 c. 63 ze zm. [dalej: ENG Act 1975].

Zob. Inheritance (Provision for Family and Dependants) (Northern Ireland) Order 1979 No. 924 (N.I. 8) ze zm. [dalej: Ni Order 1979].

20 Tak np. w prawie Manitoby (The Dependants Relief Act 1990, C.C.S.M. c. D37 ze zm. [dalej: мв Act 1990])i Ontario (Succession Law Reform Act, R.S.O. 1990, c. S.26 ze zm. [dalej: on Act 199o]).

21 Tak np. w prawie Wiktorii (\$ 90 def. eligible person [w:] Administration and Probate Act 1958 no. 6191 ze zm. [dalej: vic Act 1958], Nowej Południowej Walii (Succession Act 2006, no. 80 ze zm. [dalej: Nsw Act 2006]), Australii Południowej [Inheritance (Family Provision) Act 1972 no. 32 ze zm. [dalej: sA Act 1972]), Australii Zachodniej (Family Provision Act 1972, no. 57 ze zm. [dalej: wA Act 1972]) i Terytorium Północnego (Family Provision Act 1970, no. 10, ze zm. [dalej: NT Act 1970]). Zob. Family Protection Act 1955, no. 88 ze zm. [dalej: nZ Act 1955].

23 Ustawa ta uległa niedawno zmianom na skutek wejścia w życie Inheritance and Trustees' Powers Act 2014 c. 16. 
(konkubentów), dzieci spadkodawcy, tzw. dzieci rodziny (children of the family) i osoby utrzymywane przez spadkodawcę (dependants). Poszczególne kategorie podmiotów wymagają bliższej analizy. Przyjmuje się przy tym, że uprawniony powinien przeżyć spadkodawcę ${ }^{24}$.

Zaliczenie do kręgu uprawnionych pozostałego przy życiu małżonka spadkodawcy (wife, husband, spouse ${ }^{25}$ ) odpowiada powszechnemu zapatrywaniu prawodawców krajów common law ${ }^{26}$. Wstąpienie

24 Tak: $\$ 1(1)$ ENG Act 1975.

25 Ustalenie znaczenia terminu „spouse” wymaga każdorazowo analizy unormowań danego państwa common law. Zazwyczaj oznacza on małżonka, jednakże na potrzeby niektórych ustaw ochronnych przyjmuje się znaczenie szersze, obejmujące również np. konkubentów. Tak np. w prawie Kolumbii Brytyjskiej (\$2(1)(b) Wills, Estates and Succession Act, S.B.C. 2009, c. 13 [dalej: BC Act 2009]), Ontario ( $\$ 57$ ON Act 1990), Nunavut ( $\$ 1$ Dependants Relief Act, R.S.N.W.T. 1988, c. D-4 ze zm. [dalej: NU Act 1988]), Terytoriów Północno-Zachodnich ( 1 Dependants Relief Act, R.S.N.W.T. 1988 ze zm., c. D-4 [dalej: NW T Act 1988] oraz \$ 1 Family Law Act, R.S.N.W.T. 1997, c. 18 ze zm.), Tasmanii (\$ 2 i 3A(a) Testator’s Family Maintenance Act 1912, no. 7 ze zm. [dalej: TAS Act 1912] oraz $\$ 4$ Relationships Act 2003, no. 44 ze zm. [dalej: TAs Act 2003]), Queensland (\$5AA(1) Succession Act 1981, no. 69 ze zm. [dalej: QLD Act 1981]).

26 Tak w prawie angielskim $(\$ 1(1)(a)$ ENG Act 1975), północnoirlandzkim $(\$ 3(1)$ (a) NI Order 1979), irlandzkim (\$109 Succession Act 1965, no. 27 [dalej: IRL Act 1965], szkockim (\$\$ 11(4) i 36(1) sCT Act 1964 i common law), nowozelandzkim $(\$ 3(1)(a)$ NZ Act 1955). Tak również powszechnie w unormowaniach kanadyjskich: Kolumbii Brytyjskiej ( $\$ 60$ i $\$ 2(1)$ BC Act 2009), Alberty (\$72(b)(1) Wills and Succession Act, Statutes of Alberta 2010, c. 12.2 ze zm. [dalej: AB Act 2010]), Manitoby (\$\$ 1 i 2 M B Act 1990), Ontario (jednakże tylko wtedy, gdy spadkodawca łożył na utrzymanie małżonka bezpośrednio przed śmiercią lub był do tego zobowiązany; zob. $\$ \$ 57$ i 58 on Act 1990), Saskatchewan $(\$ 2(1)$ The Dependants Relief Act, S.S. 1996, c. D-25.01 ze zm. [dalej: sk Act 1996]), Nowego Brunszwiku ( $\$ 1$ Provision for Dependants Act, R.S.N.B. 2012, c. 111 [dalej: NB Act 2012] oraz $\$ \$ 111$ i 112(1) Family Services Act, S.N.B. 1980, c. F-2-2 ze zm. [dalej: NB Act 1980]), Wyspy Księcia Edwarda (\$1(d)(i) Dependants of a Deceased Person Relief Act, R.S.P.E.I. 1988, c. D-7 ze zm. [dalej: PE Act 1988]), Nowej Szkocji ( $\$ 2$ (b) i $\$ 3$ NS Act 1989), Nowej Fundlandii i Labradoru (\$ 2 NL Act 1990), Nunavut ( $\$ 1$ NU Act 1988), Terytoriów Północno-Zachodnich ( $\$ 1$ NWT Act 1988), Jukonu ( $\$ \$ 1$ i 2 Dependants Relief Act, R.S.Y. 2002, c. 56 [dalej: y t Act 2002]; 
w nowy związek małżeński po śmierci spadkodawcy nie pozbawia odnośnego uprawnienia ${ }^{27}$. Za małżonka w rozumieniu $\$ 25$ (4) powołanej ustawy uważa się także osobę, która w dobrej wierze wstąpiła ze spadkodawcą w związek małżeński dotknięty nieważnością (void) ${ }^{28}$, chyba że małżeństwo to za życia spadkodawcy uległo rozwiązaniu (dissolved), stwierdzono jego nieważność (annulled) lub też osoba ta za życia spadkodawcy wstąpiła w kolejny związek małżeński lub związek partnerski (tzw. civil partnership). Nie pozbawia uprawnienia samo tylko zawarcie małżeństwa unieważnialnego (voidable), jeśli małżeństwo to nie zostało za życia spadkodawcy rozwiązane lub unieważnione (annuled) ${ }^{29}$. Małżonek pozostający ze spadkodawcą

jak również w regulacjach australijskich: Nowej Południowej Walii (\$ 57(1)(a) Nsw Act 2006), Australii Południowej (\$ 6(a) SA Act 1972), Australii Zachodniej $(\$ 7(1)(a)$ WA Act 1972), Tasmanii ( $\$ 3 A(a)$ TAS Act 1912), Queensland ( $\$ 41(1)$ W ZW. Z \$5AA(1)(a) QLD Act 1981), Australijskiego Terytorium Stołecznego (\$ 7(1) (a) Family Provision Act 1969, A1969-15 ze zm. [dalej: ACT Act 1969]; przy czym wystarczy, aby dana osoba była małżonkiem spadkodawcy w dowolnym czasie), Terytorium Północnego (\$7(1)(a) NT Act 1970), Wiktorii (\$ 90 pkt. (a) def. eligible person w vic Act 1958).

27 Zob. C. Sawyer, M. Spero, Succession, wills and probate, dz. cyt., s. 328.

28 Wedle prawa angielskiego małżeństwo nieważne (void marriage) nie wywołuje skutków prawnych, nie istnieje w świetle prawa, w odróżnieniu od małżeństwa unieważnialnego (voidable marriage), które wywołuje skutki do czasu jego unieważnienia na mocy orzeczenia sądowego ze skutkiem ex tunc. Przesłanki nieważności i unieważnialności małżeństwa określają $\$ \$ 11$ i 12 Matrimonial Causes Act 1973 C. 18 ze zm. Por. także C. Sawyer, M. Spero, Succession, wills and probate, dz. cyt., s. 327; M. Butrymowicz, P. Kroczek, Angielskie prawo rodzinne, Lublin 2015, s. 81n. Zob. także \$2(5) NI Order 1979 (Irlandia Północna).

29 Por. R. Kerridge, Parry \& Kerridge the law of succession, London 2009, s. 181; A. Borkowski, Textbook on succession, Oxford 2002, s. 26o. Podobnie np. w prawie Nowego Brunszwiku (jednakże w razie zawarcia w dobrej wierze małżeństwa nieważnego przesłanką uznania za osobę uprawnioną jest pozostawanie przez małżonków we wspólnym pożyciu przez co najmniej rok przed śmiercią spadkodawcy; zob. $\$ 1$ NB Act 2012 i $\$ 111$ NB Act 1980), jak również Ontario i Manitoby (nie pozbawia uprawnienia zawarcie małżeństwa nieważnego lub 
w orzeczonej separacji również należy do kręgu uprawnionych, chyba że jego uprawnienie z omawianej ustawy zostało wyłączone na wniosek spadkodawcy przez sąd w orzeczeniu o separacji lub wydanym później ( $\$ 15$ ustawy) $)^{30}$.

Pomimo rozwodu, unieważnienia małżeństwa lub orzeczenia separacji sąd, jeśli uzna to za właściwe, może traktować pozostałą przy życiu osobę nadal jako uprawnionego małżonka w rozumieniu analizowanej ustawy, jeśli spadkodawca zmarł przed upływem 12 miesięcy od daty uprawomocnienia się orzeczenia rozwodowego unieważniającego małżeństwo lub od daty orzeczenia o separacji ${ }^{31}$. Ma to znaczenie ze względu na uprzywilejowaną pozycję małżonka na tle omawianej ustawy ${ }^{32}$.

Do kręgu uprawnionych należy również były małżonek spadkodawcy (former spouse), którego związek małżeński za życia spadkodawcy uległ rozwiązaniu lub unieważnieniu ${ }^{33}$. Pozbawia uprawnienia wstą-

unieważnialnego w dobrej wierze; zob. $\$ \$ 1$ i 57 ON Act 1990 oraz $\$ \$ 1$ i 2 M B Act 1990). Por. także prawo Alberty ( $\$ 72(d)$ AB Act 2010).

30 Tak również: R. Kerridge, Parry\& Kerridge..., dz. cyt., s. 181. Por. na tle prawa nowozelandzkiego N. Richardson, Nevill's law of trusts, wills and administration, Wellington 2013, s. 507.

31 Dodatkową przesłanką jest brak zasądzenia na rzecz wspomnianej osoby alimentów lub innego świadczenia majątkowego od spadkodawcy w trybie $\$ 23$ lub 24 Matrimonial Causes Act 1973 c. 18. Zob. szerzej o tej przesłance $\$ 14$ ENG Act 1975.

32 Zob. szerzej na temat tzw. surviving spouse standard w pkt. 3.1 niniejszej pracy.

33 Zob. \$1(1)(b) i \$25(1) ENG Act 1975. Tak również w prawie północnoirlandzkim: $\$ 3(1)(b)$ NI Order 1979. Analogiczne unormowania przewidziano np. w prawie Irlandii ( $\$ 18$ Family Law (Divorce) Act 1996 no. 33 ze zm.), Ontario (gdy spadkodawca łożył na utrzymanie małżonka bezpośrednio przed śmiercią lub był do tego zobowiązany; $\$ 57$ ON Act 1990), Manitoby (w razie orzeczenia o zobowiązaniu alimentacyjnym spadkodawcy; \$\$ 1 i 2 M A Act 1990), Wyspy Księcia Edwarda i Jukonu (jeżeli przez trzy lata poprzedzające śmierć spadkodawca łożył na utrzymanie rozwiedzionego małżonka; $\$ 1(\mathrm{~d})(\mathrm{v})$ PE Act 1988 oraz $\$ 1$ YT Act 2002. Podobnie do prawa Ontario w prawie Tasmanii ( $\$ 3 A(d)$ TAS Act 1912, 
pienie następnie w związek małżeński lub partnerski, choćby był to związek nieważny lub unieważnialny ${ }^{34}$. Uprawnienie byłego małżonka spadkodawcy może zostać również wyłączone na wniosek spadkodawcy przez sąd w orzeczeniu rozwodowym unieważniającym małżeństwo lub wydanym później ( $\$ 15$ omawianej ustawy) ${ }^{35}$.

Na skutek niedawnych zmian prawo angielskie, także na potrzeby analizowanej ustawy, dopuszcza małżeństwa osób tej samej płci ${ }^{36}$. Do katalogu uprawnionych zalicza także partnerów i byłych partnerów w ramach związków partnerskich osób tej samej płci (tzw. civil partnership), regulując ich sytuację prawną w sposób analogiczny do sytuacji małżonków, co rzutuje również na pozostałe kategorie podmiotów uprawnionych ${ }^{37}$. Zmiany prawa angielskiego wpisują się w tendencję legislacyjną dostrzegalną w ostatniej dekadzie również $\mathrm{w}$ niektórych innych krajach common law ${ }^{38}$.

Terytorium Północnego ( $\$ 7(1)(b)$ oraz $\$ 7(2)$ NT Act 1970), Australii Zachodniej $(\$ 7(1)(b)$ WA Act 1972), Queensland (\$5AA(2)(c) i $\$ 5 A A(4)$ QLD Act 1981). Zob. także prawo Australii Południowej ( $\$ 6(\mathrm{~b})$ sA Act 1972), Nowej Południowej Walii $(\$ 57(1)(d)$ NSw Act 2006), Wiktorii (\$90 pkt (e) def. eligible person w vic Act 1958).

34 Zob. \$1(1)(b) i \$25(5) i (5A) ENG Act 1975.

35 Zob. także orzeczenie w sprawie Re Fullard, [1982] Fam 42, w którym sąd zasadniczo wykluczył roszczenie byłego małżonka w sytuacji, w której w procesie rozwodowym uregulowano sprawy majątkowe stron po rozwodzie, chyba że byłoby to usprawiedliwione istotną zmianą okoliczności. Por. szerzej na ten temat: C. Sawyer, M. Spero, Succession, wills and probate, dz. cyt., s. 328.

36 Zob. Marriage (Same Sex Couples) Act 2013 c. 30 (a zwłaszcza Schedule 3 dotyczący kwestii terminologicznych).

37 Zob. zwłaszcza \$1(1)(a) i (b), \$14A, \$15ZA, \$25(1) i n. ENG Act 1975, jak również Civil Partnership Act 2004, c. 33 ze zm.. Por. także R. Kerridge, Parry \& Kerridge..., dz. cyt., s. 164 .

38 Małżeństwa osób tej samej płci unormowano m.in. w prawie kanadyjskim (zob. zwłaszcza \$2(1) i $\$ 4$ Civil Marriage Act, S.C. 2005, c. 33 ze zm.), nowozelandzkim ( $\$ 5$ Marriage (Definition of Marriage) Amendment Act 2013, no. 20), szkockim ( $\$$ 4(1) Marriage and Civil Partnership (Scotland) Act 2014 asp 5) i w unormowaniach niektórych stanów usA. Tak np. w prawie Kalifornii ( $\$ 300$ Family 
Code, 1992 Cal. Legis. Serv. Ch. 162, A.B. 2650 ze zm.; zob. także orzeczenia Sądu Najwyższego usA: Hollingsworth et al. v. Perry et al. z 26 czerwca 2013 r., 570 U.S. (2013) i Sądu Najwyższego Kalifornii: In re Marriage Cases, 2008, 43 Cal. 4th 757, 183 P.3d 384), Illinois ( $\$ \$ 750$ ILCS 5/201 i 5/220 Illinois Marriage and Dissolution of Marriage Act, P.A. 8o-923 ze zm.), Connecticut ( $\$ 46 \mathrm{~b}-20$ General Statutes Annotated, 1978, P.A. 78-230 ze zm.; zob. także orzeczenie Sądu Najwyższego Connecticut z 2008 r.: Kerrigan et al. v. Commissioner of Public Health et al., 2008, 289 Conn. 135, 957 A.2d 407), Waszyngtonu (\$26.04.010(3) Washington Revised Code, 1963 c 230 ze zm.), New Hampshire (\$ 457:1-a New Hampshire Revised Statutes Annotated, 2009, 59:1), Rhode Island (\$15-1-1 General Laws of Rhode Island Annotated, G.L. 1956, \5-1-1), Hawajów (\$572-1 Hawaii Revised Statutes, Laws 1969, c. 152 ze zm.). Na dalsze zmiany legislacyjne prawa amerykańskiego wpłynie zapewne orzeczenie z dnia 26 czerwca 2015 r. w sprawie Obergefell et al. v. Hodges, Director, Ohio Department of Health et al., 576 U.S. (2015), w którym Sąd Najwyższy Stanów Zjednoczonych Ameryki orzekł, że czternasta poprawka do Konstytucji nakłada na stanowych prawodawców obowiązek legalizacji małżeństw osób tej samej płci. Orzeczenie to zapadło w stosunku 5:4 głosów (por. zwłaszcza zdania odrębne do orzeczenia, w których podniesiono brak kompetencji sądu i konieczność pozostawienia rozstrzygnięcia o dopuszczalności tych małżeństw legislaturom stanowym). Ponadto za wprowadzeniem małżeństw osób jednej płci opowiedziano się w irlandzkim referendum przeprowadzonym w maju 2015 roku. Małżeństw tych nie dopuszcza natomiast prawo australijskie. Sprzeciwia się temu wprowadzona do $\$ 5$ federalnego Marriage Act 1961, no. 12 ze zm. (przez Marriage Amendment Act 2004, no. 126) definicja małżeństwa jako związku kobiety i mężczyzny. Ze względu na tę definicję Sąd Najwyższy Australii w sprawie The Commonwealth of Australia v. The Australian Capital Territory [2013] HCA 55, uznał za niezgodną z australijskim prawem federalnym ustawę Marriage Equality (Same Sex) Act 2013, A2013-39, uchwaloną przez parlament Australijskiego Terytorium Stołecznego, w której prawodawca stanowy podjął próbę uregulowania instytucji małżeństwa osób tej samej płci. Związki partnerskie odnośnych osób (civil partnership, civil union, domestic partnership, significant relationship) dopuszczono natomiast m.in. w prawie szkockim (\$131 Civil Partnership Act 2004, c. 33 ze zm. oraz Marriage and Civil Partnership (Scotland) Act 2014 asp 5), północnoirlandzkim (Civil Partnership Act 2004, c. 33 ze zm. oraz $\$ 3(1)(a, b)$ NI Order 1979), irlandzkim (Civil Partnership and Certain Rights and Obligations of Cohabitants Act 2010, no. 24 ze zm., dalej jako: IRL Act 2010). Podobnie w prawie nowozelandzkim (Civil Union Act 2004, no. 102 ze zm. oraz $\$ 3(1)$ NZ Act 1955), australijskim i niektórych stanów UsA. Zob. np. prawo Australii Południowej ( $\$ \$ 11$ i 11A Family Relationships Act 1975, no. 115 ze zm. [dalej: sA Act 1975], Tasmanii (\$ 2 i 3A(a,e) TAs Act 1912 oraz 
Do katalogu uprawnionych wedle prawa angielskiego należy konkubent spadkodawcy, jeżeli przez pełen okres dwóch lat bezpośrednio poprzedzających śmierć spadkodawcy pozostawał ze spadkodawcą we wspólnym pożyciu odpowiadającym małżeńskiemu lub charakterystycznym dla związku partnerskiego ${ }^{39}$. Ustawowego zwrotu „living in the same household” nie należy zatem ograniczać jedynie do wspólnego zamieszkiwania ${ }^{40}$. W orzecznictwie na ogół przyjmuje się, że brak pożycia fizycznego czy jedynie przemijająca przerwa $\mathrm{w}$ trakcie wymaganego okresu pożycia nie pozbawia uprawnień przy-

$\$ 4$ TAS Act 2003), Australijskiego Terytorium Stołecznego ( $\$ 169$ Legislation Act 2001, A2001-14 ze zm., Domestic Relationships Act 1994, A1994-28 ze zm., Civil Unions Act 2012, A2012-40 ze zm. oraz $\$ 7$ (1,9) ACT Act 1969), Queensland ( $\$ 4$ Relationships Act 2011, no. 46 ze zm. oraz $\$ 5 A A(2)($ ba) QLD Act 1981), Wiktorii (Relationships Act 2008, no. 12 ze zm.), Kalifornii $(\$ 297(b)(4)(A)$ i $\$$ 297.5(a) Family Code, 1992 Cal. Legis. Serv. Ch. 162 (A.B. 2650) ze zm.), Delaware (tytuł 13, \$201 Delaware Code, 78 Laws 2011, c. 22), Rhode Island (\$ 15-3.1-1 General Laws of Rhode Island Annotated, G.L. 1956, \$5-1-1 ze zm.) i Vermont (tytuł 15, \$1202 Vermont Statutes Annotated, 1999, Adj. Sess., No. 91).

Tak: $\$ 1(1)(b a),(1 A)$ i (1B) ENG Act 1975. Wobec przywołanych wcześniej zmian legislacyjnych utraciła znaczenie dotychczasowa linia orzecznicza sądów angielskich, które odmówiły uznania za konkubentów osób tej samej płci. Zob. np. Fitzpatrick v. Sterling Housing Association (1999), 2 FLR 1027; Rees v UK [1987], 2 FLR 111; Cossey v UK [1991], 2 FLR 492. Zob. R. Kerridge, Parry \& Kerridge..., dz. cyt., s. 189, przyp. 203. Podobnie na tle prawa irlandzkiego ( $\$ 172(1)$ IRL Act 2010) i kanadyjskiego. Zob. np. stanowiące punkt zwrotny orzeczenie Sądu Najwyższego Kanady w sprawie M. v. H. [1999], 2 S.C.R. 3 ogłoszone jeszcze przed wspomnianymi zmianami legislacyjnymi. Por. także J. MacKenzie, A. Kope, M. Shebbeare, Halsbury's laws of Canada. Wills and estates, Markham 2012, s. 466. Tak również na tle prawa australijskiego. Zob. np. prawo Australii Południowej ( $\$ 4$ SA Act 1972 oraz \$11 SA Act 1975); Tasmanii (\$2 i 3 A (a,e) TAs Act 1912 oraz $\$ 4$ TAS Act 2003), Terytorium Północnego ( $\$ 3$ A (3) De Facto Relationships Act 1991, no. 38 ze zm.), Australii Zachodniej ( $\$ 13 \mathrm{~A}(1)$ w Zw. z $\$ 13 \mathrm{~A}(3)$ (a) Interpretation Act 1984, no. 12) Nowej Południowej Walii (\$21C Interpretation Act 1987, no. 15 ze zm.), Queensland (\$32DA(5)(a) Acts Interpretation Act 1954, 3 Eliz 2 no. 3 ze zm.). Zob. także ustawę nowozelandzką (\$2D Property (Relationships) Act 1976, no. 166 ze zm.).

Zob. np. A. Borkowski, Textbook on succession, dz. cyt., s. 268. 
znanych analizowaną ustawą ${ }^{41}$. Konkubentów (określanych czasem jako tzw. common law partners) zalicza się do kręgu uprawnionych także w uregulowaniach niektórych innych krajów common law (np. Irlandii ${ }^{42}$, Irlandii Północnej ${ }^{43}$, Nowej Zelandii ${ }^{44}$, prowincjach kanadyjskich i stanach australijskich ${ }^{45}$ ).

41 Zob. np. orzeczenie w sprawie Witkowska v Kaminski (2006), EWHC 1940, w której sąd uznał, że wspólne pożycie nie ustało w sytuacji, gdy spadkodawca zmarł w dniu powrotu konkubiny do Anglii po trzymiesięcznej wizycie u rodziny w Polsce. Por. szerzej: C. Sawyer, M. Spero, Succession, wills and probate, dz. cyt., s. 330; R. Kerridge, Parry \& Kerridge..., dz. cyt., s. 189 i powołane tam orzeczenia. Zob. $\$ \$ 172(5)$ i 194 IRL Act 2010, które po spełnieniu określonych przesłanek przyznają również uprawnienie byłemu konkubentowi spadkodawcy.

43 Tak \$ $3(1)(\mathrm{ba}),(1 \mathrm{~A}),(1 \mathrm{~B})$ NI Order 1979.

44 Zob. $\$ 3(1)(\mathrm{aa})$ i $\$ 4$ A NZ Act 1955.

45 Prowincje kanadyjskie - tytułem przykładu, prawo Saskatchewan wymaga wspólnego pożycia małżeńskiego przez nieprzerwany okres dwóch lat, choć za wystarczający uznaje pozostawanie w związku faktycznym o określonych podstawach trwałości, jeśli w związku tym urodziło się dziecko (\$ 2(1) SK Act 1996). Zbliżone rozwiązania przyjęto w prawie Nowego Brunszwiku ( $\$ 1$ NB Act 2012 oraz $\$ 112(3)$ NB Act 1980, z tą różnicą, że wymagany okres wspólnego pożycia wynosi trzy lata, a ponadto $\mathrm{w}$ każdym przypadku, również w razie posiadania wspólnego dziecka, konkubenci powinni żyć wspólnie przez rok przed śmiercią spadkodawcy), Nunavut ( $\$ 1$ NU Act 1988; z tym zastrzeżeniem, że wystarczy wspólne pożycie przez jeden rok, jeżeli spadkodawca łożył na utrzymanie konkubenta), Terytoriów Północno-Zachodnich (wymagane wspólne pożycie konkubentów przez co najmniej jeden rok bezpośrednio poprzedzający śmierć spadkodawcy i pozostawanie na utrzymaniu spadkodawcy, jednakże wymogów tych nie stosuje się, jeśli konkubenci zostali rodzicami; $\$ 1$ NWT Act 1988), Ontario (w razie gdyby konkubenci pozostawali we wspólnym pożyciu przez co najmniej trzy lata lub zostali rodzicami naturalnymi lub adopcyjnymi, jednakże w każdym z tych przypadków konkubent jest uprawniony wyłącznie wtedy, gdy spadkodawca łożył na jego utrzymanie bezpośrednio przed śmiercią lub był do tego zobowiązany; $\$ \$ 57$ i 58 on Act 1990), a także w prawie Manitoby (które wprowadza wymóg wspólnego pożycia przez co najmniej trzy lata lub też jeden rok, gdy konkubenci są rodzicami wspólnego dziecka, a także przyznaje uprawnienie ochronne również wówczas, gdy relacja faktyczna ustała w ciągu trzech lat poprzedzających śmierć spadkodawcy lub gdy spadkodawca na mocy orzeczenia sądowego lub umowy był bezpośrednio przed swoją śmiercią zobowiązany do świadczeń 
Wedle angielskiej ustawy z 1975 roku uprawnionymi są dzieci spadkodawcy ${ }^{46}$, w tym poczęte, lecz jeszcze nienarodzone do chwili

alimentacyjnych na rzecz byłego partnera; $\$ 1$ мв Act 1990). Wedle prawa Kolumbii Brytyjskiej znaczenie ma natomiast długość wspólnego pożycia, które powinno trwać co najmniej dwa lata przed śmiercią spadkodawcy (\$60 i \$2(1)(b) BC Act 2009). Podobnie w prawie Jukonu (\$ 1 Y T Act 2002; wymóg wspólnego pożycia przez okres co najmniej 12 miesięcy poprzedzających śmierć spadkodawcy). Prawo Alberty natomiast przyznaje uprawnienie osobie pozostającej ze spadkodawcą w relacji współzależności pomiędzy dorosłymi (adult interdependent relationship), szeroko ujmując jej zakres. Chodzi bowiem o relację osób związanych więzami uczuciowymi i finansowymi, prowadzących wspólne życie. Tak szerokie pojęcie obejmuje zatem zarówno wspólne pożycie charakterystyczne dla konkubentów, jak i przypadki, w których osoby spokrewnione, związane przysposobieniem lub jedynie zaprzyjaźnione, decydują się na dzielenie obowiązków życiowych, lecz nie pozostają w związku faktycznym odpowiadającym pożyciu małżeńskiemu. Tak: $\$ 72($ b)(ii) A B Act 2010 oraz $\$ 1(1)(f), \$ 3(1), \$ 4(1)$ Adult Interdependent Relationships Act 2002 (Statutes of Alberta 2002, c. A-4.5 ze zm.).

Stany australisjkie - prawo Australii Południowej za uprawnionego uznaje tzw. partnera życiowego (domestic partner), przez którego rozumie się osobę, która pozostawała ze spadkodawcą we wspólnym pożyciu nieprzerwanie przez trzy lata bezpośrednio poprzedzające śmierć spadkodawcy lub też w sumie trzy lata w ciągu ostatnich czterech lat życia spadkodawcy, lecz za wystarczające uznaje się pozostawanie w związku, z którego pochodzi wspólne dziecko konkubentów ( $\$ \$ 4$ i 6 SA Act 1972 oraz $\$ 11$ A sA Act 1975). Podobne rozwiązania przyjęto np. w prawie Australijskiego Terytorium Stołecznego (\$ 7(9)(b)(ii-iii) ACT Act 1969) i Wiktorii $(\$ 3(1)$ def. domestic partner I unregistered domestic partner w zw. z $\$ 90$ VIC Act 1958). Prawo Queensland wymaga natomiast co najmniej dwuletniego wspólnego pożycia konkubentów bezpośrednio przed śmiercią spadkodawcy (\$ 41(1) i §5AA(2)(b) QLD Act 1981). Zob. także prawo Nowej Południowej Walii, w którym nie wprowadzono wymogu co do okresu wspólnego pożycia konkubentów (\$57(1)(b) NSw Act 2006). Podobnie w prawie Tasmanii, w którym dodatkowo za uprawnionego uznano również konkubenta, w razie gdyby związek ze spadkodawcą ustał za jego życia, lecz spadkodawca łożył na utrzymanie byłego konkubenta lub był do tego zobowiązany na mocy orzeczenia sądowego lub umowy ( $\$ 2$ i $3 A(a, e)$ TAs Act 1912 oraz $\$ 4$ TAs Act 2003). Podobnie w prawie Terytorium Północnego ( $\$ 7(1)(b)$ i $\$ 7(2,7)$ NT Act 1970) i Australii Zachodniej $(\$ 7(1)(a, b)$ wA Act 1972). Por. także prawo Wiktorii (\$ 90 viC Act 1958).

46 Odpowiada to powszechnej tendencji w systemach common law. Zob. również prawo kanadyjskich prowincji i terytoriów: Alberty (\$72(b)(iii-v) AB Act 2010), 
śmierci spadkodawcy (en ventre sa mere, nasciturus) ${ }^{47}$, a także dzieci przysposobione $^{48}$. Dla samej tylko przynależności do kategorii uprawnionych nie ma znaczenia wiek dziecka ani jego stan cywilny ${ }^{49}$.

Manitoby (\$1 MB Act 1990), Nowej Szkocji (\$ $2(a)$ i $\$ 3(1)$ Ns Act 1989), Kolumbii Brytyjskiej (\$60 BC Act 2009), Nowej Fundlandii i Labradoru (\$ 2 NL Act 1990), Wyspy Księcia Edwarda ( $\$ 1(d)($ ii-iii) PE Act 1988), Jukonu (\$1 Y T Act 2002), Terytoriów Północno-Zachodnich ( $\$ 1$ Nw T Act 1988), Nowego Brunszwiku ( 1 NB Act 2012 i $\$ 113(1)$ NB Act 1980), Ontario (jednakże tylko wtedy, gdy spadkodawca łożył na utrzymanie dziecka bezpośrednio przed śmiercią lub był do tego zobowiązany; $\$ \$ 57$ i 58 on Act 1990), Nunavut ( $\$ 1$ NU Act 1988, z tym zastrzeżeniem, że pojęcie dziecka obejmuje na potrzeby wspomnianej ustawy także pasierba). Na tle prawa australijskiego zob. prawo Australii Południowej (\$6(c) SA Act 1972), Tasmanii ( $\$ 3 A(b)$ i $\$ 2$ TAs Act 1912), Australijskiego Terytorium Stołecznego $(\$ 7(1)(c)$ ACT Act 1969), Terytorium Północnego $(\$ 7(1)(c)$ NT Act 1970), Australii Zachodniej (\$7(1)(c) wA Act 1972), Nowej Południowej Walii $(\$ 57(1)(c)$ NSw Act 2006), Wiktorii ( $\$ 90$ pkt. (b) i (f) def. eligible person W VIC Act 1958), Queensland ( $\$ 40$ i 41(1) QLD Act 1981). Zob. także prawo nowozelandzkie ( $\$ 3(1)(b)$ NZ Act 1955), irlandzkie ( $\$ 117$ IRL Act 1965) i północnoirlandzkie $(\$ 3(1)(\mathrm{c})$ NI Order 1979).

47 Tak $\$ 25(1)$ ENG Act 1975. Tak również np. w prawie: Irlandii Północnej (\$ 2(2) NI Order 1979), Alberty (\$72(b)(iii) AB Act 2010), Nowej Szkocji (\$2(a) i § 3(1) Ns Act 1989), Manitoby ( $\$ 1$ мB Act 1990), Nowej Fundlandii i Labradoru (\$ 2 NL Act 1990), Wyspy Księcia Edwarda (\$1 PE Act 1988), Saskatchewan (\$ 2(1) SK Act 1996), Jukonu (\$1 Y Act 2002), Nunavut (\$1 NU Act 1988), Terytoriów Północno-Zachodnich ( $\$ 1$ NWT Act 1988), Ontario (\$1(1) on Act 1990), Australijskiego Terytorium Stołecznego ( $\$ 7(8)$ ACT Act 1969), Terytorium Północnego ( $\$ 7(8)$ NT Act 1970), Australii Zachodniej (\$ 7(1)(c) wA Act 1972), Queensland ( $\$ 5 A$ QLD Act 1981).

48 Zob. $\$ 39$ Adoption Act 1976, c. 36 ze zm. Tak również powszechnie w prawie kanadyjskim (por. J. MacKenzie, A. Kope, M. Shebbeare, Halsbury's..., s. 467) i australijskim (por. G. E. Dal Pont, K. F. Mackie, Law of succession, dz. cyt., s. 508-531. Zob. np. prawo Nowej Szkocji (\$2(a) i \$ 3(1) NS Act 1989), Nowej Fundlandii i Labradoru ( $\$ 2$ NL Act 1990), Saskatchewan (\$2(1) SK Act 1996), Nunavut ( $\$ 1$ NU Act 1988), Terytoriów Północno-Zachodnich ( $\$ 1$ NWT Act 1988), Tasmanii ( $\$ 2(1)$ TAs Act 1912), Queensland ( $\$ 40$ QLD Act 1981), Wiktorii (\$90 pkt (b) def. eligible person w vic Act 1958).

49 Por. A. Borkowski, Textbook on succession, dz. cyt., s. 262; C. Sawyer, M. Spero, Succession, wills and probate, dz. cyt., s. 331. Odmiennie jednak np. w prawie Manitoby, wedle którego dziecko testatora jest uprawnione jedynie wówczas, 
Przez tzw. dzieci rodziny (children of the family) uznaje się natomiast osoby, które nie będąc dziećmi spadkodawcy, były przez niego traktowane jak dzieci rodziny utworzonej w związku z zawartym przez spadkodawcę małżeństwem lub związkiem partnerskim ${ }^{50}$. Chodzi zatem przede wszystkim o pasierbów ${ }^{51}$, choć definicja ustawy angiel-

gdy w chwili śmierci testatora nie ukończyło 18 lat, pozostawało na utrzymaniu spadkodawcy lub też ze względu na chorobę, niepełnosprawność czy z innego powodu nie było zdolne do samodzielnego zaspokajania swoich potrzeb życiowych (\$ 1 MB Act 1990). Podobnie do prawa Manitoby także w prawie Wyspy Księcia Edwarda (\$1(d)(ii-iii) PE Act 1988), Saskatchewan (\$2(1) SK Act 1996), Jukonu ( $\$ 1$ Y T Act 2002; granica wieku: 16 lat), Nunavut (\$1 NU Act 1988; wiek graniczny: 19 lat), Terytoriów Północno-Zachodnich ( $\$ 1$ NWT Act 1988; wiek graniczny: 19 lat) i Nowego Brunszwiku ( $\$ 1$ NB Act 2012 i $\$ 113(1)$ NB Act 1980). Prawo Alberty natomiast przewiduje dodatkowo, że do uprawnionych należy dziecko spadkodawcy, które ukończyło 18 lat, lecz nie 22 lata i studiuje w pełnym wymiarze $(\$ 72(\mathrm{~b})(\mathrm{v})$ AB Act 2010).

50 Zob. $\$ 1(1)(d)$ ENG Act 1975. Na tle prawa północnoirlandzkiego zob. \$3(1)(d) NI Order 1979. Podobne unormowania zawarto w prawie Manitoby (\$1 MB Act 1990) i Ontario ( $\$ 57$ ON Act 1990), uznając osobę, względem której spadkodawca pełnił rolę rodzica za dziecko spadkodawcy, co nie obejmuje jednak sytuacji, gdy spadkodawca pełnił jedynie odpłatnie funkcję rodzica zastępczego. W kwestii przesłanek roszczenia, które znajdują zastosowanie do dziecka spadkodawcy w prawie Manitoby por. przyp. 50, w prawie Ontario por. przyp. 47. Prawo Alberty przyznaje natomiast uprawnienie wnukom i prawnukom spadkodawcy, wobec których spadkodawca pełnił rolę rodzica, jeśli w chwili śmierci spadkodawcy nie ukończyły 18 lat ( $\$ 72(\mathrm{~b})(\mathrm{vi})$ A B Act 2010). Wedle prawa Wiktorii natomiast uprawnionym jest osoba, która przez znaczny okres czasu uważała, że jest naturalnym dzieckiem spadkodawcy i w taki też sposób była przez niego traktowana (\$ 9o pkt (d) i (g) def. eligible person w vic Act 1958).

51 Podobnie np. w prawie Australii Południowej (jednakże tylko wówczas, gdy spadkodawca bezpośrednio przed śmiercią łożył na utrzymanie pasierba lub też był do tego zobowiązany; $\$ 6$ (g) sA Act 1972), Australijskiego Terytorium Stołecznego $(\$ 7(1)(d)$ i $\$ 7(2)$ ACT Act 1969), Terytorium Północnego $(\$ 7(1)(d)$ i $\$ 7(2)$ NT Act 1970), Australii Zachodniej (\$ 7(1)(ea, eb) wA Act 1972; przy czym pasierb jest również uprawniony w sytuacji, gdy spadkodawca otrzymał lub jest uprawniony do otrzymania określonej korzyści majątkowej ze spadku po rodzicu pasierba, choćby spadkodawca nie był zobowiązany do łożenia na utrzymanie pasierba i tego nie czynił). Por. także prawo nowozelandzkie $(\$ 3(1)(d)$ NZ Act 
skiej jest szersza niż tradycyjne rozumienie tego zwrotu. Podobnie jak w przypadku dzieci spadkodawcy, prawnie obojętny jest tu wiek i stan cywilny uprawnionego ${ }^{52}$. Istotna jest natomiast odpowiednia intencja spadkodawcy. Nie wystarczy bowiem obdarzenie danej osoby uczuciem; konieczne jest, aby spadkodawca traktował daną osobę jako dziecko rodziny przez wzgląd na zawarty związek, choćby nawet związek ten następnie ustał ${ }^{53}$. Nowelizacja z 2014 roku znacznie rozszerzyła omawianą kategorię, obejmując nią także osoby, względem których spadkodawca pełnił faktycznie rolę rodzica, choćby nawet nie pozostawał z nikim związany ${ }^{54}$.

Zaliczenie do dotychczas omówionych kategorii uprawnionych nie jest wedle prawa angielskiego zależne od pozostawania na utrzymaniu spadkodawcy. W niektórych systemach common law krąg tych osób kształtuje się jeszcze szerzej, obejmując np. wnuki spadkodawcy ${ }^{55}$,

1955). Bez potrzeby spełnienia przesłanki pozostawania na utrzymaniu spadkodawcy pasierbów zalicza do kręgu uprawnionych prawo: Nunavut ( $\$ 1 \mathrm{NU}$ Act 1988), Terytoriów Północno-Zachodnich ( $\$ 1$ NwT Act 1988), Nowego Brunszwiku ( $\$ 1$ NB Act 2012 i $\$ 1$ NB Act 1980), Tasmanii ( $\$ 3 A(b)$ i $\$ 2(1)$ TAs Act 1912), Queensland ( $\$ 40$ W Zw. z $\$ 41(1)$ QLD Act 1981), Wiktorii ( $\$ 90$ pkt. (c) i (f) def. eligible person w vic Act 1958). W myśl unormowań niektórych krajów common law pasierbem jest również dziecko konkubenta spadkodawcy. Zob. prawo Nowej Zelandii (\$3(1)(d) NZ Act 1955), Australii Południowej (\$ 6(g) SA Act 1972), Australii Zachodniej ( $\$$ 4(1) wA Act 1972).

52 Zob. R. Kerridge, Parry \& Kerridge..., dz. cyt., s. 195.

53 Por. C. Sawyer, M. Spero, Succession, wills and probate, dz. cyt., s. 333; A. Borkowski, Textbook on succession, dz. cyt., s. 262-263.

54 Zob. $\$ 1(1)(d)$ i $\$ 1(2 A)$ ENG Act 1975 o treści nadanej przez $\$ 2$ Schedule 2 Inheritance and Trustees' Powers Act 2014, c. 16.

55 Tak np. w prawie Nowej Zelandii $(\$ 3(1)(c)$ NZ Act 1955), Australii Południowej (\$6(h) sA Act 1972), jak również Australijskiego Terytorium Stołecznego i Terytorium Północnego (gdy rodzic wnuka, który jest dzieckiem spadkodawcy, zmarł przed spadkodawcą lub gdy jeden z rodziców lub obydwoje nie łożyli na utrzymanie wnuka bezpośrednio przed śmiercią spadkodawcy; zob. $\$ 7(1)$ (e) i $\$ 7(3)$ ACT Act 1969 oraz $\$ 7(1)($ e) i $\$ 7(3)$ NT Act 1970). 
jego rodziców ${ }^{56}$, rodzeństwo ${ }^{57}$, matkę dziecka spadkodawcy ${ }^{58}$ czy osobę pozostającą w bliskiej relacji osobistej ze spadkodawcą ${ }^{59}$.

Wymienione powyżej kategorie nie wyczerpują jednak katalogu uprawnionych wedle prawa angielskiego. Oddzielną grupę uprawnionych tworzą bowiem osoby, na których utrzymanie łożył spadkodawca (dependants). Jest to grupa wyjątkowo szeroka, ponieważ nie wprowadzono tu ograniczeń osobowych. Pozwala to na wywodzenie roszczeń przez członków rodziny nienależących do wcześniejszych kategorii (np. wstępnych i zstępnych spadkodawcy dalszych niż dzieci czy rodzeństwo spadkodawcy), jak również inne osoby (np. przyjaciół $\left.1^{60}\right)^{61}$. Zgodnie $\mathrm{z} \$ 1$ (3) ustawy z 1975 roku przesłanką zaliczenia do kręgu uprawnionych jest choćby częściowe pozostawanie na utrzymaniu spadkodawcy. Wymóg ten uważa się za spełniony, gdy spadkodawca bezpośrednio przed śmiercią spełniał znaczne świadczenia majątkowe w celu za-

56 Zob. unormowania Australii Zachodniej (\$7(1)(e) wA Act 1972), Tasmanii (gdy spadkodawca nie pozostawił małżonka ani dzieci; $\$ 3 A(c)$ TAs Act 1912), Australii Południowej i Nowego Brunszwiku (jeśli rodzic wykaże, że przyczyniał się do utrzymania spadkodawcy w sposób majątkowy lub osobisty; \$ 6(i) sA Act 1972 oraz $\$ 114$ NB Act 1980 w ZW. z $\$ 1$ NB Act 2012).

57 Tak w prawie Australii Południowej, jeśli brat lub siostra wykażą, że przyczyniali się do utrzymania spadkodawcy bądź to przez świadczenia majątkowe, bądź też osobistym staraniem ( $\$ 6(j)$ sA Act 1972).

58 Por. prawo Nowego Brunszwiku ( $\$ 112(2)$ NB Act 1980 w zw. z $\$ 1$ NB Act 2012).

59 Tak w prawie Nowej Południowej Walii $(\$ 57(1)(\mathrm{f})$ NSw Act 2006). Ustawa stanowa definiuje bliską relację osobistą jako relację między osobami dorosłymi, niekoniecznie spokrewnionymi, polegającą na wspólnym życiu, obdarzaniu się wsparciem i osobistą opieką, przy czym relacja ta nie polega na pożyciu odpowiadającym małżeńskiemu ( $\$ 3(3)$ Nsw Act 2006).

60 Tak np. w sprawie Rees v. Newbery [1998], 1 FLR 1041, w której za uprawnionego uznano przyjaciela spadkodawcy, któremu spadkodawca wynajmował mieszkanie po stawce znacznie niższej niż rynkowa.

61 Zob. \$1(1) Eng Act 1975. Por. także R. Kerridge, Parry \& Kerridge..., dz. cyt., s. 196; A. Borkowski, Textbook on succession, dz. cyt., s. 263; C. Sawyer, M. Spero, Succession, wills and probate, dz. cyt., s. 335 . 
spokajania rozsądnych potrzeb tej osoby. Świadczenia te nie mogą być jednak spełniane w wykonaniu odpłatnej umowy handlowej ${ }^{62}$. Dla zaliczenia do omawianej kategorii osób ma znaczenie również to, aby spadkodawca uznał, że przyjmuje na siebie odpowiedzialność za utrzymanie osoby uprawnionej, przy czym w orzecznictwie z samego faktu świadczenia wywodzi się domniemanie, że tak właśnie było ${ }^{63}$.

Kategorię osób, na których utrzymanie łożył spadkodawca, przewidują również przepisy niektórych innych krajów common law. $\mathrm{Na}$ ogól jednak ogranicza się ją do osób pozostających ze spadkodawcą w określonej relacji: wnuków spadkodawcy ${ }^{64}$, jego zstępnych

62 Tak $\$ 1(3)$ ENG Act 1975 po nowelizacji dokonanej $\S_{3}$ Schedule 2 Inheritance and Trustees' Powers Act 2014, c. 16). Sekcja 1(3) ENG Act 1975 sprzed nowelizacji nie przewidywała natomiast kryterium handlowego charakteru relacji, co skutkowało trudnościami interpretacyjnymi w sytuacji, w której osoby utrzymywane przez spadkodawcę spełniały na jego rzecz świadczenia np. w postaci opieki. Tak np. w sprawie Re Wilinson [1978], 1 All ER 211, w której za uprawnioną uznano siostrę spadkodawczyni, która nieodpłatnie zamieszkiwała ze spadkodawczynią, uczestnicząc $w$ wypełnianiu obowiązków domowych. Po porównaniu rozmiaru wzajemnych świadczeń sąd wykluczył odpłatny charakter świadczenia spadkodawczyni (nieodpłatne udostępnienie mieszkania). Jednakże obecna treść \$1 (3) ENG Act 1975 również może stanowić źródło rozbieżnych interpretacji: potencjalnie może stwarzać drogę dla roszczeń osób, które łączyły ze spadkodawcą odpłatne umowy niezwiązane z działalnością gospodarczą żadnej ze stron. Aby zapobiec popadnięciu w przeciwną skrajność wskutek tej zmiany ustawowej, należałoby położyć nacisk na kryterium „,utrzymania” ( to maintain) danej osoby przez spadkodawcę, co z góry zakłada jednak nierównorzędność świadczeń.

63 Zob. Jelley v. Iliffe [1981], 2 All ER 29; Re Beaumont [1950], Ch 462.

64 Tak w prawie Manitoby ( $\$ 1$ MB Act 1990), Ontario ( $\$ \$ 57$ i 58 on Act 1990), Nowej Południowej Walii ( $\$ 57(1)(\mathrm{e})$ Nsw Act 2006), Wiktorii (\$9o pkt (i) def. „elligible person”w zw. z $\$$ 91(2)(b) vic Act 1958), Australii Zachodniej (gdy rodzic wnuka będący dzieckiem spadkodawcy zmarł przed spadkodawcą lub gdy spadkodawca łożył na utrzymanie wnuka bezpośrednio przed swoją śmiercią; $\$ 7(1)(\mathrm{d})$ wA Act 1972). Zob. także prawo Wyspy Księcia Edwarda i Jukonu (zob. \$1(d)(iv) PE Act 1988 i $\$ 1$ Y T Act 2002 uzależniające ochronę dziadków, rodziców, wnuków i dalszych zstępnych spadkodawcy od tego, czy spadkodawca łożył na ich utrzymanie przez co najmniej trzy lata bezpośrednio poprzedzające jego śmierć). 
dalszych niż wnuki ${ }^{65}$, rodziców ${ }^{66}$, dziadków $^{67}$, rodzeństwa ${ }^{68}$, osób pozostających ze spadkodawcą we wspólnym gospodarstwie domowym (household) ${ }^{69}$ czy niektórych innych jeszcze kategorii ${ }^{70}$.

\section{Mechanizm ochrony osób uprawnionych}

W omawianych systemach prawnych można spotkać różne mechanizmy ochrony osób uprawnionych przed pozbawieniem korzyści

65 Tak w prawie Wyspy Księcia Edwarda (zob. $\$ 1(d)($ iv) PE Act 1988) i Jukonu (\$1 Y T Act 2002).

66 Tak w prawie Manitoby (\$1 м в Act 1990), Wyspy Księcia Edwarda (zob. \$1(d) (iv) PE Act 1988), Jukonu ( $\$ 1$ Y T Act 2002), Ontario ( $\$ 57$ i $\$ 58(1)$ on Act 1990; przy czym unormowanie to obejmuje pojęciem rodzica spadkodawcy także osobę, która uznawała spadkodawcę za tzw. child of the family), Queensland ( $\$ 40$ W ZW. z $\$ 41(1)(a)$ QLD Act 1981), Australijskiego Terytorium Stołecznego, Terytorium Północnego i Nowej Zelandii (przy czym wymogu utrzymania przez spadkodawcę nie stosuje się w sytuacji, gdy spadkodawca nie pozostawił małżonka, partnera ani dzieci; $\$ 7(1)(f), \S 7(4)$ i $\$ 7(7)$ ACT Act 1969; $\$ 7(1)(f)$ w zw. $\mathrm{z} \$ 7(4)$ i $\$ 7(7)$ NT Act 1970; jak również $\$ 3(1)(e)$ i $\$ 3(1 A)$ NZ Act 1955).

67 Tak w prawie Manitoby (\$1 MB Act 1990), Wyspy Księcia Edwarda (zob. \$1(d) (iv) PE Act 1988), Jukonu ( $\$ 1$ Y T Act 2002), Ontario ( $\$ 57$ i $\$ 58(1)$ on Act 1990).

68 Tak w prawie Manitoby ( $\$ 1$ MB Act 1990) i Ontario ( $\$ 57$ i $\$ 58(1)$ on Act 1990$)$.

69 Tak w prawie Nowej Południowej Walii $(\$ 57(1)($ e) NSw Act 2006) i Wiktorii $(\$ 90$ pkt $(\mathrm{k})$ def. eligible person w vic Act 1958). Por. szerzej G. E. Dal Pont, K. F. Mackie, Law of succession, dz. cyt., s. 513.

70 Wśród uprawnionych w ramach kategorii osób uzależnionych finansowo od spadkodawcy uregulowanie stanu Queensland wymienia rodzica dziecka spadkodawcy, które nie ukończyło 18 roku życia, jak również osobę, która nie ukończyła tego wieku (bez dookreślenia jednak relacji wiążącej ze spadkodawcą). Zob. \$40 w zw. z \$ 41(1) (b-c) QLD Act 1981. Prawo Wiktorii z kolei wymienia małżonka lub partnera dziecka spadkodawcy (w tym pasierba lub dziecka uznawanego przez spadkodawcę za jego dziecko naturalne) zmarłego przed upływem roku od dnia śmierci spadkodawcy ( $\$ 90$ pkt (j) def. eligible person w vic Act 1958). Według unormowań Nunavut i Terytoriów Północno-Zachodnich ochronie podlega natomiast osoba, która pełniła funkcję rodzica zastępczego dla dzieci spadkodawcy (\$1 NU Act 1988 oraz \$1 NWT Act 1988). 
ze spadku. W ramach jednego z modeli to sąd, przy uwzględnieniu całokształtu okoliczności, powinien ustalić wysokość i rodzaj świadczenia należnego uprawnionemu (model dyskrecjonalnej władzy sądu). Inne zaś systemy przyznają określone uprawnienia, nie pozostawiając miejsca dla uznania sądu. Na podobnym założeniu oparto systemy rezerwy i zachowku, znane w porządkach prawnych Europy kontynentalnej ${ }^{71}$. Spotyka się wreszcie rozwiązania pośrednie, czerpiące wzorce z obydwu ujęć skrajnych.

\subsection{Model dyskrecjonalnej władzy sądu}

Model dyskrecjonalny zdobył znaczną popularność wśród krajów common law. Jego założenia przyjęto zwłaszcza w prawie angielskim ${ }^{72}$, północnoirlandzkim ${ }^{73}$, kanadyjskim ${ }^{74}$, australijskim, nowozelandz-

71 Tak np. w prawie polskim, przewidującym instytucję zachowku (art. 991 i n. k.c.). Nie jest ona jednak pozbawiona cech uznaniowych. Trafnie bowiem dopuszcza się korzystanie w wyjątkowych przypadkach z kompetencji uznaniowej sądu w ramach oceny zarzutu nadużycia prawa podmiotowego (art. 5 k.c.), umożliwiającej nawet całkowite oddalenie powództwa o zachowek. Zob. zwłaszcza uchwałę Sądu Najwyższego z dnia 19 maja 1981 r., III CZP 18/81, OSNC 1981, nr 12, poz. 228, wyroki z dnia 25 stycznia 2001 r., IV CKN 250/oo; z dnia 7 kwietnia 2004 r., IV CK 215/03, Państwo i Prawo 2005, z. 6, s. 111 oraz postanowienie z dnia 11 lipca 2012 r., I CSK 75/12, Glosa 2013, nr 2, s. 82.

72 Zob. Inheritance (Provisions for Family and Dependants) Act 1975, c. 63 ze zm.

73 Tak: Inheritance (Provision for Family and Dependants) (Northern Ireland) Order 1979, No. 924 (N.I. 8) ze zm.

74 Zob. wymienione dotychczas: Family Relief Act, R.S.N.L. 1990, c. F-3 ze zm. (Nowa Fundlandia i Labrador), Testators' Family Maintenance Act, R.S.N.S. 1989, c. 465 (Nowa Szkocja), The Dependants' Relief Act, S.S. 1996, c. D-25.01 ze zm. (Saskatchewan), Wills, Estates and Succession Act, S.B.C. 2009, c. 13 (Kolumbia Brytyjska), Wills and Succession Act, Statutes of Alberta 2010, c. W-12.2 ze zm. (Alberta), Succession Law Reform Act, R.S.O. 1990, c. S.26 ze zm. (Ontario), The Dependants Relief Act 1990, C.C.S.M. c. D37 ze zm. (Manitoba), Dependants of a Deceased Person Relief Act, R.S.P.E.I. 1988, c. D-7 ze zm. (Wyspa Księcia Edwarda), Provision for Dependants Act, R.S.N.B. 2012, c. 111 (Nowy Brunszwik), Dependants Relief Act, R.S.N.W.T. 1988, c. D-4 ze zm. (Terytoria 
$\mathrm{kim}^{75}$. Choć prawo nowozelandzkie jest $\mathrm{w}$ tej mierze prekursorem ${ }^{76}$, to jednak ze względu na zdecydowanie większą rolę emigracji do Anglii należy konsekwentnie poddać bliższej analizie przede wszystkim unormowania tego kraju.

W modelu dyskrecjonalnym zakres i treść uprawnienia osoby bliskiej spadkodawcy określa sąd przy uwzględnieniu całokształtu okoliczności. W rezultacie, działając na wniosek uprawnionego, sąd jest władny skorygować skutki testamentowego lub ustawowego ${ }^{77}$ porządku dziedziczenia po danym spadkodawcy, poprzez przyznanie osobie uprawnionej określonego świadczenia ze spadku. Wskazane w ustawie osoby mogą bowiem domagać się świadczenia majątko-

Północno-Zachodnie), Dependants Relief Act, R.S.N.W.T. 1988, c. D-4 ze zm. (Nunavut), Dependants Relief Act 2002, c. 56 (Jukon).

75 Australia - zob. wspomniane już: $\$ 90$ i n. Administration and Probate Act 1958, no. 6191 ze zm. (Wiktoria), Testator's Family Maintenance Act 1912, no. 7 ze zm. (Tasmania), Family Provision Act 1972, no. 57 ze zm. (Australia Zachodnia), $\S 40$ Succession Act 1981, no. 69 ze zm. (Queensland), $\$ 55$ i n. Succession Act 2006, no. 80 ze zm. (Nowa Południowa Walia), Inheritance (Family Provision) Act 1972, no. 32 ze zm. (Australia Południowa), Family Provision Act 1970, no. 10 ze zm. (Terytorium Północne), Family Provision Act 1969, A1969-15 ze zm. (Australijskie Terytorium Stołeczne).

Nowa Zelandia - Family Protection Act 1955, no. 88 ze zm.

$76 \mathrm{~W}$ prawie tym po raz pierwszy wprowadzono omawianą instytucję w Testator's Family Maintenance Act 1900, no. 20.

77 Podobnie np. w prawie Irlandii Północnej [\$ 4(1) NI Order 1979], Nowej Zelandii [\$ 4(1) NZ Act 1955], Australii Południowej [\$ 7(1) SA Act 1972], Tasmanii [\$ 3(1) TAS Act 1912], Australii Zachodniej [ $\$ 6(1)$ WA Act 1972], Terytorium Północnego [\$ 8(1) NT Act 1970], Australijskiego Terytorium Stołecznego [\$ 8(2) ACT Act 1969], Nowej Południowej Walii [ $\$ 59(1)(c)$ NSw Act 2006], Wiktorii [\$ 91(2)(d) vic Act 1958], Queensland [ $\$ 41(1)$ QLD Act 1981], Nowej Fundlandii i Labradoru [ $\$ 3(1)$ NL Act 1990], Nowego Brunszwiku [\$ 2(1) NB Act 2012], Nunavut [\$ 2(1) NU Act 1988], Terytoriów Północno-Zachodnich [\$ 2(1) NWT Act 1988], Manitoby [\$ 2(2) мв Act 1990], Alberty [\$ 88(1) AB Act 2010]. Do przypadków dziedziczenia testamentowego ograniczono natomiast zakres unormowań Nowej Szkocji [\$ 3(1) Ns Act 1989], Kolumbii Brytyjskiej ( $\$ 60$ BC Act 2009) i Irlandii [\$ 109(1) IRL Act 1965]. 
wego (financial provision), wywodząc, że wskutek dziedziczenia nie otrzymały rozsądnego przysporzenia. Brak jest przy tym konkretnych wskazań ustawowych co do sposobu obliczenia wysokości świadczenia należnego uprawnionemu ${ }^{78}$.

Sąd powinien zatem ustalić zarówno to, czy z wnioskiem wystąpiła osoba uprawniona ${ }^{79}$, jak i to, czy uprawniony otrzymał rozsądne przysporzenie w drodze spadkobrania.

78 Por. np. A. Borkowski, Textbook on succession, dz. cyt., s. 253; C. Sawyer, M. Spero, Succession, wills and probate, dz. cyt., s. 339; M. A. Zachariasiewicz, Zachowek czy rezerwa? Głos $w$ dyskusji nad potrzebami i kierunkami zmian polskiego prawa spadkowego, „Rejent” 2006, nr 2, s. 188-189.

79 Uprawniony powinien wystąpić $\mathrm{z}$ wnioskiem w terminie 6 miesięcy od daty wydania pierwszego tzw. grant of representation, który nie został następnie odwołany. Sąd może zezwolić na złożenie wniosku po terminie ( $\$ 4$ ENG Act 1975). Por. także A. Borkowski, Textbook on succession, dz. cyt., s. 272; C. Sawyer, M. Spero, Succession, wills and probate, dz. cyt., s. 324. Wedle prawa angielskiego grant of representation jest orzeczeniem przyjmującym postać tzw. grant of probate (orzeczenia stwierdzającego ważność testamentu, podejmowanego w razie, gdy spadkiem zarządza wykonawca testamentu) albo tzw. letters of administration (wydawanego w razie, gdy spadkiem podlegającym dziedziczeniu ustawowemu lub testamentowemu zarządza administrator). Por. szerzej na ten temat np. B. Kucia, Dokumentowanie..., s. 16-17. Podobne rozwiązanie co do terminu przyjęto $\mathrm{w}$ unormowaniach innych krajów common law. Tak w prawie Irlandii Północnej (\$ 6 NI Order 1979), Australii Południowej ( $\$ 8$ SA Act 1972), Australii Zachodniej [\$ 7(2) wA Act 1972], Australijskiego Terytorium Stołecznego [\$ 9(1) ACт Act 1969], Wiktorii [\$ 99(1) VIC Act 1958], Nowej Szkocji [ $\$ 14(1)$ Ns Act 1989], Nowej Funlandii i Labradoru [\$ 14(1) NL Act 1990], Saskatchewan [\$ 4(1) sk Act 1996], Wyspy Księcia Edwarda [\$ 13(1) PE Act 1988], Jukonu [\$ 14(1) Y T Act 2002], Nunavut [\$ 13(1) NU Act 1988], Terytoriów Północno-Zachodnich [\$13(1) NWT Act 1988], Ontario [\$ 61(1) on Act 1990], Manitoby [\$ 6(1) MB Act 1990], Alberty [\$ 89(1) AB Act 2010]. Termin trzymiesięczny wprowadzono w prawie Tasmanii [\$11(4) TAs Act 1912], termin roczny natomiast w prawie Terytorium Północnego [\$ 9(1) NT Act 1970] i Nowej Zelandii [\$ 9(1) NZ Act 1955, a w przypadku osób niepełnoletnich lub niemających wymaganej zdolności umysłowej - termin dwuletni]. Od chwili śmierci spadkodawcy termin liczy się natomiast w prawie Nowej Południowej Walii [\$ 58(2) Nsw Act 2006 dwanaście miesięcy], Queensland [\$41(8) QLD Act 1981 - dziewięć miesięcy] i Nowego Brunszwiku [ $\$ 16(1)$ NB Act 2012 - cztery miesiące]. W prawie australijskim 
Rozmiar otrzymanego przysporzenia ze spadku podlega ocenie wedle kryterium obiektywnego, nie zaś subiektywnych odczuć uprawnionego. Prawnie relewantne jest bowiem to, czy uprawniony uzyskał rozsądną korzyść, a nie to, czy spadkodawca działał racjonalnie ${ }^{80}$. Prawo angielskie przewiduje przy tym obszerny katalog okoliczności, którymi powinien kierować sąd oceniający sprawę ${ }^{81}$. Katalog ten nakazuje w szczególności mieć wzgląd na rozmiar i skład spadku, sytuację majątkową i osobistą uprawnionego i spadkobierców, ich potrzeby, obowiązki prawne lub moralne spadkodawcy względem nich i inne jeszcze okoliczności ${ }^{82}$.

i kanadyjskim powszechnie przy tym ogranicza się możliwość złożenia wniosku o przedłużenie wymaganego terminu przez wzgląd na dokonany dział spadku. 80 Tak: Re Goodwin, [1968] 3 All ER 12. Por. A. Borkowski, Textbook on succession, dz. cyt., s. 274-275; C. Sawyer, M. Spero, Succession, wills and probate, dz. cyt., s. 340. Podobnie np. w prawie kanadyjskim. Zob. J. MacKenzie, A. Kope, M. Shebbeare, Halsbury's..., dz. cyt., s. 474.

81 Podobnie np. w prawie Australijskiego Terytorium Stołecznego [\$ 8(3) ACT Act 1969], Nowej Południowej Walii (\$60 Nsw Act 2006), Wiktorii [ $\$ 91 A(2)$ vIC Act 1958], Ontario ( $\$ 62$ oN Act 1990), Nowej Szkocji [\$ 5(1) ns Act 1989], Nowej Fundlandii i Labradoru [ $\$ 5(1)$ NL Act 1990], Wyspy Księcia Edwarda (\$ 5 PE Act 1988), Nunavut ( $\$ 4$ NU Act 1988), Manitoby ( $\$ 8$ M A Act 1990), Alberty (\$93 AB Act 2010). W prawie kanadyjskim i australijskim można ponadto spotkać unormowania upoważniające sąd do odmowy uwzględniania żądania uprawnionego w razie, gdyby przemawiał za tym charakter lub sposób postępowania uprawnionego. Tak np. w prawie Australii Południowej [\$ 7(3) sA Act 1972], Australii Zachodniej [\$ 6(2) WA Act 1972], Queensland [ $\$ 41(2)(c)$ QLD Act 1981], Tasmanii [ $\$ 8(1)$ TAS Act 1912], Terytorium Północnego [ $\$ 8(3)$ NT Act 1970], Nowej Szkocji [ $\$ 5(1)(a)$ Ns Act 1989], Nowej Fundlandii i Labradoru [\$ 5(1)(a) NL Act 1990], Saskatchewan [\$ 8(6) SK Act 1996], Nowego Brunszwiku (\$ 4 NB Act 2012), Wyspy Księcia Edwarda [\$ 5(1)(c) PE Act 1988], Jukonu [\$ 5(1)(d) Y T Act 2002], Nunavut [\$ 4(1) (d) NU Act 1988], Terytoriów Północno-Zachodnich [\$ 4(1)(d) NwT Act 1988].

82 Sąd powinien uwzględnić także ewentualną niezdolność do pracy uprawnionego i spadkobierców, ich stan zdrowia, relacje ze spadkodawcą, jak również życzenia samego spadkodawcy i pochodzenie jego majątku. W przypadku małżonków, partnerów i konkubentów spadkodawcy relewantny jest także czas trwania związku i stopień przyczynienia się do powstania majątku spadkodawcy. Zob. 
Uwzględnieniu podlega również to, do której kategorii uprawnionych należy osoba dochodząca roszczenia. Zależnie od tego ustawa odmiennie kształtuje pojęcie rozsądnego przysporzenia ze spadku, co wpływa pośrednio także na rozmiar przysługującego roszczenia. Małżonek ${ }^{83}$ jest przy tym traktowany łagodniej (tzw. surviving spouse standard $)^{84}$. W jego przypadku sąd bierze bowiem pod uwagę to, jakie przysporzenie byłoby rozsądne w świetle ogółu okoliczności. Uprawnienie małżonka nie ogranicza się jedynie do pokrycia kosztów utrzymania (maintenance). Należy także uwzględniać to, jakiego przysporzenia mógłby małżonek rozsądnie oczekiwać, w razie gdyby małżeństwo ze spadkodawcą ustało przez rozwód, a nie śmierć spadkodawcy $^{85}$. W odniesieniu do pozostałych uprawnionych znajduje

\$ 3 ENG Act 1975. Por. także R. Kerridge, Parry \& Kerridge..., dz. cyt., s. 179-180; M. A. Zachariasiewicz, Zachowek..., dz. cyt., s. 189.

83 Dotyczy to również partnera w związku partnerskim (civil partner). Zatem poczynione w tym kontekście uwagi co do małżonka należy odnieść także do partnera. Zob. \$3(2) ENG Act 1975.

84 Standard ten nie ma zastosowania do małżonka, który w chwili śmierci spadkodawcy pozostawał z nim w separacji, chyba że sąd inaczej postanowi w przypadku określonym w $\$ 14$ ENG Act 1975. Tak również w odniesieniu do byłego małżonka spadkodawcy. Por. także przyp. 31.

85 Tak $\$ 1(2)(a)$ w zw. $z \$ 3(2)$ ENG Act 1975. W niektórych orzeczeniach na tle omawianej ustawy sądy nawiązywały do zasad orzekania w sprawach rozwodowych. Przyjmowano wówczas, że za punkt wyjścia należy obrać przyznanie małżonkowi świadczenia odpowiadającego wartością od jednej trzeciej do połowy spadku. Por. orzeczenie w sprawie Moody v. Stevenson [1992] 2 All ER 524; Wachtel v. Wachtel [1973] 1 All ER 829; White v. White [200o] 2 FLR 981. Trafnie zwraca się jednak uwagę, że nie jest tu możliwa pełna analogia. W sprawach ocenianych na podstawie ustawy z $1975 \mathrm{r}$. analizie podlega wszak sytuacja małżonka pozostałego przy życiu i spadkobierców, nie zaś dwojga małżonków. Ponadto można zwrócić uwagę na mało stanowczą treść odesłania do zasad rozwodowych, zawartego w $\$ 3(2)$ ENG Act 1975. W rezultacie spotyka się także orzeczenia, w których przyjmuje się, że kryteria orzekania w sprawach rozwodowych stanowią tylko jedną z wielu wytycznych na tle ustawy z 1975 r. Por. A. Borkowski, Textbook on succession, dz. cyt., s. 275n.; R. Kerridge, Parry \& Kerridge..., dz. cyt., s. 183. 
natomiast zastosowanie standard surowszy (tzw. maintenance standard), w myśl którego rozsądnym przysporzeniem jest tylko takie, które w świetle okoliczności pozwala na pokrycie kosztów utrzymania. $\mathrm{Na}$ ogół chodzi tu o koszty przeciętnego utrzymania, odpowiadające pozycji życiowej uprawnionego, przy czym niekoniecznie takiego utrzymania, do którego uprawniony przywykł tuż przed śmiercią spadkodawcy ${ }^{86}$. Należy zatem zauważyć, że sąd nie jest całkowicie swobodny w zakresie oceny przesłanek roszczenia.

W razie ustalenia, że ziściły się przesłanki roszczenia, sąd ma szerokie kompetencje w zakresie kształtowania treści rozstrzygnięcia (tzw. order). Umożliwia to wydanie orzeczenia adekwatnego do okoliczności sprawy ${ }^{87}$. Katalog dopuszczalnych rozstrzygnięć obejmuje:

Zob. także orzeczenia w sprawach: Re Besterman [1984] 2 All ER 656; Re Burning [1984] 3 All ER 1; Re Krubert [1996] 3 WLR 959.

86 W przypadku jednak, gdy z roszczeniem występują dorosłe dzieci, wskazane, choć nie zawsze wymagane w orzecznictwie jest, aby spadkodawcy można było przypisać moralny obowiązek świadczenia na ich utrzymanie (np. związany z chorobą dziecka lub zerwaniem przez spadkodawcę kontaktu z dzieckiem podejmującym starania o odzyskanie kontaktu). Por. np. sprawę Re Coventry [1979] 2 All ER 408. Zdolność do samodzielnego utrzymania się dorosłego dziecka spadkodawcy zmniejsza jego szanse na otrzymanie korzyści na podstawie omawianej ustawy. W niełatwej sytuacji jest również były małżonek spadkodawcy. Z reguły uzyskuje on bowiem wskutek rozwodu określony majątek, co uniemożliwia mu zasadniczo dochodzenie uprawnień na podstawie ustawy z 1975 roku. Sam tylko wzrost wartości majątku spadkodawcy po rozwodzie na ogół nie uzasadnia roszczenia na podstawie ustawy z 1975 roku. Byłemu małżonkowi może natomiast przysługiwać roszczenie, w razie gdyby spadkodawca, który przez dłuższy okres po rozwodzie łożył na jego utrzymanie, nie przewidział na jego rzecz rozrządzenia w testamencie. Podobnie w razie gdyby spadkodawca zmarł niedługo po rozwodzie. Por. sprawy Re Fullard [1981] 2 All ER 796; Re Crawford (1983) 4 FLR 273. Por. także A. Borkowski, Textbook on succession, dz. cyt., s. 280-286 (prawo angielskie); B. E. Spierin, The succession act 1965 and related legislation. A commentary, Haywards Heath 2011, s. 356, 368 (prawo irlandzkie).

87 Podobne rozwiązania przyjęto w uregulowaniach Nowej Zelandii ( $\$ 5 \mathrm{NZ}$ Act 1955), Australii Południowej [\$ 7(4) sa Act 1972], Tasmanii [\$3(2) TAs Act 1912], 
zasądzenie świadczenia pieniężnego ${ }^{88}$, nakazanie przeniesienia lub obciążenia prawa wchodzącego do spadku ${ }^{89}$ (któremu może towarzyszyć nakaz uprzedniego nabycia tego prawa ze środków pochodzących ze spadku ${ }^{90}$ ), zmiana umowy zawartej pomiędzy spadkodawcą i jego małżonkiem na korzyść tego ostatniego, dziecka pochodzącego z tego małżeństwa lub dziecka uznawanego za dziecko rodziny z uwagi na to małżeństwo (tzw. children of the family) ${ }^{91}$.

Wydane w omawianym trybie orzeczenie wiąże spadkobierców zmarłego ${ }^{92}$. Przeznaczone im przedmioty spadkowe mogą posłużyć

Australii Zachodniej [\$ 6(4) WA Act 1972], Terytorium Północnego [\$11(1) NT Act 1970], Nowej Południowej Walii [\$\$59(2), 65 i 66 Nsw Act 2006], Wiktorii (\$96 VIC Act 1958), Queensland [ $\$ 41(2)$ QLD Act 1981], Nowej Szkocji [ $\$ 6(2)$ Ns Act 1989], Nowej Fundlandii i Labradoru [ $\$ 6(2-3)$ NL Act 1990], Saskatchewan [ $\$ \$$ 6-7 SK Act 1996], Nowego Brunszwiku [\$\$ 2(2)(a), 8 i 9NB Act 2012], Wyspy Księcia Edwarda ( $\$ 6$ PE Act 1988), Jukonu (\$\$ 6-8 y T Act 2002), Nunavut (\$\$ 5 i 7 NU Act 1988), Terytoriów Północno-Zachodnich (\$\$ 5 i 7 NwT Act 1988), Ontario ( $\$ 63$ ON Act 1990), Manitoby ( $\$ 9$ MB Act 1990), Kolumbii Brytyjskiej (\$\$ 63-64 BC Act 2009), Alberty [\$ 96(1)(b) AB Act 2010]. Zob. także prawo północnoirlandzkie [ $\$ 4(1)$ NI Order 1979].

88 Tak: $\$ 3(a-b)$ ENG Act 1975. Zasądzone świadczenie pieniężne może przyjąć postać sumy płatnej jednorazowo, w ratach lub nawet świadczeń okresowych. To ostatnie orzeczenie może być następnie zmienione lub uchylone stosownie do okoliczności. W razie natomiast, gdyby świadczenie okresowe przyznano na rzecz byłego małżonka lub małżonka pozostającego w separacji (odpowiednio: partnera cywilnego), wówczas orzeczenie w tym przedmiocie utraci moc w razie zawarcia przez niego związku małżeńskiego lub związku partnerskiego [ $\$ \$ 6-7$ oraz 19(2) ENG Act 1975].

89 Zob. \$2(1)(c-d) ENG Act 1975.

90 Tak: $\$ 2(1)(\mathrm{e})$ ENG Act 1975.

91 Bez względu na to, czy umowę zawarto przed, czy po zawarciu małżeństwa, a także czy spadkodawca wziął ją pod uwagę przy sporządzaniu testamentu. Zob. $\$ 2(1)(f-g)$ ENG Act 1975. Sąd może także wydać zarządzenie tymczasowe celem wsparcia finansowego uprawnionego $\mathrm{w}$ czasie trwania postępowania sądowego (tzw. interim order). Zob. \$5 ENG Act 1975.

92 Wiąże także osoby obdarowane przez spadkodawcę w przypadkach określonych w $\$ \$ 10-12$ ENG Act 1975. Por. szerzej w przyp. 99 i 100. Por. A. Borkowski, 
do wykonania orzeczenia sądu. W tym celu sąd może podjąć takie rozstrzygnięcie, jakie uzna za konieczne lub celowe. Przepis nie wprowadza w tym zakresie ograniczeń, poprzestając na ogólnym wymogu uczciwego i rozsądnego ukształtowania sytuacji uprawnionego i spadkobierców oraz przykładowym wyliczeniu możliwych rozstrzygnięć. Sąd ma zatem w tej mierze znaczną swobodę, której nie należy jednak utożsamiać $\mathrm{z}$ dowolnościąa ${ }^{93}$ Może więc w szczególności zmienić sposób podziału spadku pomiędzy spadkobierców czy nakazać spadkobiercy zapłatę sumy pieniężnej lub przeniesienie na rzecz uprawnionego oznaczonego prawa, a także ustanowić trust ${ }^{94}$.

W celu zapobieżenia próbom obejścia unormowań ochronnych prawo angielskie przyjmuje na potrzeby ustawy z 1975 roku szerokie pojęcie spadku (tzw. net estate), obejmując nim nie tylko przedmioty majątkowe zaliczane do spadku wedle zasad ogólnych ${ }^{95}$, lecz także

Textbook on succession, dz. cyt., s. 289.

93 Zob. także R. Kerridge, Parry \& Kerridge..., dz. cyt., s. 172. Zob. także prawo północnoirlandzkie [\$ 4(4) NI Order 1979]. Podobnie np. w prawie Nowej Zelandii ( $\$ 7$ NZ Act 1955), Australii Południowej [ $\$ 7(6)$ i $\$ 9$ s A Act 1972], Tasmanii ( $\$ 11 A$ TAS Act 1912), Australii Zachodniej ( $\$ 14$ WA Act 1972), Terytorium Północnego [\$11(2) NT Act 1970], Australijskiego Terytorium Stołecznego [\$\$ 11(2) i 15 АCт Act 1969], Nowej Południowej Walii [ $\$ 68$ i 72(2) NSw Act 2006], Wiktorii [\$ 97(2) VIC Act 1958], Queensland [\$ 41(3-4) QLD Act 1981], Nowej Szkocji (\$\$ 6 i 8 Ns Act 1989), Nowej Funlandii i Labradoru [\$6(3), 8 i 10 NL Act 199o], Saskatchewan [\$\$ 6(2), 11 i 12 sk Act 1996], Nowego Brunszwiku [\$\$ 2(2)(b) i 14 NB Act 2012], Wyspy Księcia Edwarda ( $\$ 10$ PE Act 1988), Nunavut [\$\$ 5(2) i 7 NU Act 1988], Terytoriów Północno-Zachodnich [\$5(2) NwT Act 1988], Ontario ( $\$ \$ 66$ i 68 on Act 1990), Manitoby (\$\$ 10 i 12 MB Act 1990), Kolumbii Brytyjskiej (\$\$ 65-68 BC Act 2009), Alberty [\$\$ 96(1)(a) i 98 A B Act 2010].

94 Tak: \$2(4) ENG Act 1975. Od uznania sądu zależy również zróżnicowanie sytuacji poszczególnych klas spadkobierców czy też nawet pozycji spadkobierców w ramach danej klasy. Zob. także orzeczenie w sprawie Re Preston, [1969] 2 All ER 961.

95 Jednakże po uprzednim zaspokojeniu długów spadkowych, obejmujących koszty pogrzebu, postępowania spadkowego i zarządu spadkiem, jak również należności podatkowych. Zob. \$25(1)(a) ENG Act 1975. Tak rozumiany spadek obejmuje 
te, które wskutek śmierci spadkodawcy przeszły na jego następców prawnych poza porządkiem dziedziczenia ${ }^{96}$. Na mocy orzeczenia sądu zakresem net estate mogą być objęte także darowizny ${ }^{97}$ lub nieodpłatne umowy o sporządzenie testamentu ${ }^{98}$, odpowiednio dokonane lub zawarte przez spadkodawcę w celu udaremnienia ochrony jego bliskich przed pozbawieniem korzyści ze spadku.

także mienie położone za granicą. Zob. Bheekhun v. Williams, [1999] 2 FLR 229. Por. także A. Borkowski, Textbook on succession, dz. cyt., s. 291.

96 Zob. \$\$ 8-9 ENG Act 1975 dotyczące tzw. statutory nominations, darowizn mortis causa, udziałów w prawach majątkowych objętych tzw. joint tenancy (w razie gdyby sąd tak postanowił). Por. także prawo Irlandii Północnej (\$\$ 10-11 NI Order 1979), Nowej Zelandii [\$ 2(5) NZ Act 1955], Nowej Południowej Walii (\$\$ 74-90 NSw Act 2006), Queensland [ $\$ 41(12)$ QLD Act 1981], Wyspy Księcia Edwarda (\$\$19-20 PE Act 1988), Jukonu (\$\$ 20-21 Y T Act 2002], Nunavut (\$\$19-21 NU Act 1988), Terytoriów Północno-Zachodnich ( $\$ \$ 19-21$ NWT Act 1988), Ontario ( $\$ 72$ on Act 1990).

97 Tak: $\$ 10$ ENG Act 1975, przy czym dotyczy to tylko umów zawartych w ciągu sześciu lat poprzedzających śmierć spadkodawcy. Sąd może włożyć na obdarowanego obowiązek zwrotu świadczenia lub jego wartości w celu umożliwienia zaspokojenia roszczenia uprawnionego wedle ustawy z 1975 roku. Odpowiedzialność obdarowanego ogranicza się jednak do wartości przedmiotu darowizny, pomniejszonej o należny podatek [ $\$ 10(3-4)$ ENG Act 1975]. Por. także prawo Irlandii Północnej ( $\$ 12$ NI Order).

98 Por. $\$ 11$ ENG Act 1975 . Wierzycielowi przysługuje roszczenie z tytułu umowy o sporządzenie testamentu o określonej treści, które, podobnie jak i ewentualne roszczenie odszkodowawcze z tytułu niewykonania tej umowy, jako dług spadkowy obniża wartość spadku (również na potrzeby ustawy z 1975 roku). W celu uniknięcia tej sytuacji dopuszczono możliwość wydania orzeczenia o obowiązku zwrotu świadczenia spełnionego na rzecz wierzyciela na podstawie takiej umowy lub obowiązku powstrzymania się ze świadczeniem (jeszcze niespełnionym). Orzeczeniem można objąć jedynie świadczenie w zakresie przekraczającym korzyść uzyskaną przez spadkodawcę na mocy wskazanej umowy. Por. także prawo Irlandii Północnej ( $\$ 13$ NI Order), Nowej Szkocji [\$ 16(1) NS Act 1989], Nowej Fundlandii i Labradoru [ $\$ 16$ NL Act 1990], Saskatchewan ( $\$ 10$ SK Act 1996), Nowego Brunszwiku [ $\$ 18$ NB Act 2012], Wyspy Księcia Edwarda ( $\$ 14$ PE Act 1988), Jukonu ( $\$ 15$ Y T Act 2002), Nunavut (\$14 NU Act 1988), Terytoriów Północno-Zachodnich ( $\$ 14$ NWT Act 1988), Ontario ( $\$ 71$ on Act 1990), Alberty $(\$ 102 \mathrm{AB}$ Act 2010). 
Omówiony model stanowi zatem przeciwieństwo tych systemów, w których obliczenie świadczenia należnego odbywa się z matematyczną precyzją, co stanowi zarówno o jego zaletach (możliwość uwzględnienia stanu dotychczasowych relacji pomiędzy spadkodawcą i członkiem jego rodziny, ich sytuacji osobistej i majątkowej, względów sprawiedliwości), lecz także i wadą (brak przewidywalności rozstrzygnięć sądowych, co stanowi niemały kłopot już na etapie podejmowania decyzji o zainicjowaniu sprawy sądowej).

\subsection{Model ustawowo określonych uprawnień}

W ramach drugiej grupy systemów prawnych ochrona interesów osób bliskich spadkodawcy następuje przez przyznanie im ściśle określonych uprawnień.

Rozwiązanie tego rodzaju obowiązuje między innymi w prawie szkockim, które małżonkowi, partnerowi cywilnemu i zstępnym spadkodawcy przyznaje tzw. legal rights ${ }^{99}$. Przysługują one ex lege od chwili śmierci spadkodawcy niezależnie od tego, czy dochodzi do dziedziczenia testamentowego czy ustawowego. $W$ ich ramach uprawnionemu przysługuje roszczenie o zapłatę sumy odpowiadającej wartości określonego udziału spadkowego.

W celu określenia wysokości roszczenia część spadku obejmującą tzw. moveables ${ }^{100}$ pozostałą po spłacie długów spadkowych dzieli się

99 Tzw. legal right jest terminem ustawowym, którym posługuje się m.in. \$36(1) SCT Act 1964. Uprawnienia te bywają także określane jako tzw. legal shares. Tak w: Scottish Law Commission, Report no. 124 on Succession, Edinburgh 1990, s. 24. Uprawnienie małżonka i zstępnych spadkodawcy wywodzi się z common law, natomiast źródłem uprawnienia partnera pozostającego ze spadkodawcą w związku partnerskim (civil partner) jest $\$ 131$ Civil Partnership Act 2004, c. 33, ze zm. Por. także H. Hiram, The Scots..., dz. cyt., s. 101 ; M. A. Zachariasiewicz, Zachowek..., dz. cyt., s. 191.

100 Moveable property należy odróżnić od tzw. heritable property (immoveables), które obejmują nieruchomości i prawa z nimi związane. Choć nazwa na to wskazuje, 
na trzy równe udziały, z których jeden może podlegać swobodnym rozrządzeniom testamentowym, pozostałe zaś dwa przypadają: po pierwsze, małżonkowi spadkodawcy albo partnerowi cywilnemu ${ }^{101}$ (tzw. ius relictae), po drugie, zstępnym spadkodawcy (tzw. legitim). Jeśli spadkodawca nie miał zstępnych lub żaden z nich nie przeżył spadkodawcy, wówczas udział małżonka wynosi połowę z części spadku obejmującej moveables. Taki sam udział przysługuje zstępnym spadkodawcy, w razie gdyby spadkodawca nie miał małżonka lub małżonek ten nie przeżył spadkodawcy. W tej sytuacji w miejsce małżonka nie wstępują inni uprawnieni ${ }^{102}$. Udział przeznaczony zstępnym przypada natomiast najpierw dzieciom spadkodawcy po równo (per capita $)^{103}$. Przy ustalaniu roszczenia przysługującego zstępnemu

nie należy utożsamiać tych konstrukcji prawnych z instytucjami prawa polskiego. Moveable property obejmuje bowiem również np. wierzytelności z tytułu deliktów i bezpodstawnego wzbogacenia, udziały w spółkach czy prawa własności intelektualnej. Por. np. G. L. Gretton, A. J. M. Steven, Property..., dz. cyt., s. 9. Por. także przyp. 5. Ograniczenie zakresu legal rights jedynie do moveable property może w konkretnej sprawie istotnie osłabić ochronę osób uprawnionych. Jak dotąd ustawodawca szkocki nie uczynił zadość zgłaszanym postulatom, zmierzającym do objęciem zakresem legal rights także immoveables. Por. Scottish Law Commission, Report no. 124..., dz. cyt., s. 20-21; Scottish Law Commission, Report no. 215 ..., dz. cyt., s. 33; G. L. Gretton, A. J. M. Steven, Property..., dz. cyt., s. 386. 101 Sytuację prawną małżonka i partnera cywilnego w analizowanym względnie unormowano w sposób tożsamy. Por. przyp. 38. W związku z tym uwagi poświęcone sytuacji małżonka w prawie szkockim należy odnieść także do partnera cywilnego spadkodawcy.

102 Zob. H. Hiram, The Scots..., dz. cyt., s. 107-108.

103 Gdyby natomiast dziecko nie przeżyło spadkodawcy, wówczas w jego miejsce wstępują jego dzieci, a więc wnuki spadkodawcy. Reguła ta znajduje odpowiednie zastosowanie również do dalszych zstępnych spadkodawcy. Wielkość udziałów przypadających zstępnym spadkodawcy określa \$11(2) SCT Act 1964 Jeśli spadkodawcę przeżyli zstępni, z których wszyscy są w tym samym stopniu spokrewnieni ze spadkodawcą (np. wnuki), część przeznaczoną zstępnym dzieli się pomiędzy nich po równo. Tak: $₫ 11(2)(a)$ omawianej ustawy. W przypadku natomiast, gdyby legitim przysługiwało zstępnym różnego stopnia, wówczas 
uwzględnia się dodatkowo darowizny ${ }^{104}$ dokonane na jego rzecz przez spadkodawcę ${ }^{105}$.

Legal rights mają zatem charakter długów spadkowych. Nie wyłączają więc testamentowych rozrządzeń częścią spadku służącą do ich ustalenia, jednakże mają one pierwszeństwo przed postanowieniami testamentu ${ }^{106}$.

istotna jest pozycja tego spośród nich, który przeżył spadkodawcę i jest w najbliższym stopniu z nim spokrewniony. Udział przypadający zstępnym dzieli się bowiem na tyle części, ilu jest lub było (w znaczeniu przeżyło lub nie przeżyło) zstępnych spadkodawcy tego samego stopnia, co ów kluczowy zstępny. Następnie, jeśli któryś z tak wydzielonych udziałów przypadł na zstępnego, który nie przeżył spadkodawcy, wówczas udział ten przypada jego dzieciom w częściach równych. Reguła ta znajduje zastosowanie również do dalszych zstępnych (per stirpes). Tak: $\$ 11(2)(\mathrm{b})$ analizowanej ustawy.

104 Zob. np. Naismith v Boyes, [1899] A.C. 495. Dotyczy to jednak tylko darowizn obejmujących moveables, które zostały dokonane przez spadkodawcę w zamiarze ich zaliczenia na poczet przyszłej korzyści, którą miałby uzyskać zstępny ze spadku po darczyńcy. Nie chodzi tu natomiast o świadczenia spełniane w ramach zwykłych obowiązków rodzinnych.

105 Uwzględnienie darowizn ma charakter jedynie rachunkowy i dotyczy wyłącznie legitim. Nie ma natomiast zastosowania do małżonka ani partnera cywilnego spadkodawcy (ius relictae). Zabieg ten polega na doliczeniu do wartości udziału spadkowego przypadającego zstępnym (legitim fund) darowizn podlegających uwzględnieniu. Następnie na poczet roszczenia danego uprawnionego zalicza się uczynione na jego rzecz darowizny, które podlegały doliczeniu. Przy obliczaniu roszczenia dalszego zstępnego uwzględnia się w odpowiedniej proporcji darowizny uczynione na rzecz jego wstępnego (będącego jednocześnie zstępnym spadkodawcy). Przedstawiony zabieg stosuje się przy tym jedynie na wniosek innego uprawnionego z tytułu legal right. Por. $\$ 11(3)$ omawianej ustawy. Zob. także szerzej: H. Hiram, The scots..., dz. cyt., s. 113-114; G. L. Gretton, A. J. M. Steven, Property..., dz. cyt., s. 393; Scottish Law Commission, Report no. 124..., dz. cyt., s. 27-28.

106 Jeśli uprawniony z tytułu legal right został powołany do spadku na mocy testamentu, wówczas powinien wybrać (tzw. election) pomiędzy przysługującym mu roszczeniem (legal right) i dziedziczeniem testamentowym. Wybór tego ostatniego nie powiększy jednak udziałów z tytułu legal rights pozostałych uprawnionych ani też, $w$ braku odmiennego zastrzeżenia, nie pozbawi uprawnionego jego legal right w odniesieniu do tych moveables spadkowych, które podlegają 
Podobne rozwiązanie przyjęto także w prawie irlandzkim w odniesieniu do małżonka i partnera cywilnego spadkodawcy (civil partner), którym przyznano tzw. legal rights. W ramach tej instytucji małżonkowi ${ }^{107}$ przysługuje $\mathrm{z}$ mocy prawa roszczenie o zapłatę sumy odpowiadającej wartości określonego udziału w spadku pozostałym po spłacie długów spadkowych ${ }^{108}$. Podstawą do wyliczenia roszczenia jest jednak, inaczej niż w prawie szkockim, udział w całym spad$\mathrm{ku}^{109}$. Małżonek rozwiedziony ${ }^{110}$, konkubent ${ }^{111}$ i dzieci spadkodawcy ${ }^{112}$

dziedziczeniu ustawowemu. Należy wszakże zauważyć, że w przypadku dziedziczenia ustawowego pierwszeństwo przed legal rights przysługuje tzw. prior rights małżonka lub partnera spadkodawcy, a w przypadku uprawnień zstępnych spadkodawcy (legitim) - również uprawnieniu konkubenta spadkodawcy do żądania korzyści ze spadku. Może to w konkretnej sprawie oznaczać, że zabraknie spadkowych moveables, które mogłyby stanowić podstawę do wyliczenia i zaspokojenia legal rights. Por. $\$ \$ 8-9$ i 10(2) sC т Act 1964, Schedule 28 Part 1 Civil Partnership Act 2004, c. 33 ze zm. oraz $\$ 29$ Family Law (Scotland) Act 2006 asp 2. Por. H. Hiram, The Scots..., dz. cyt., s. 102-103, 107-108 i 123; G. L. Gretton, A. J. M. Steven, Property..., dz. cyt., s. 386-388.

107 Prawo irlandzkie kształtuje pozycję prawną partnera cywilnego (civil partner) w odnośnym zakresie w sposób tożsamy z sytuacją małżonka. Zob. $\$ 109$ n. IRL Act 1965 oraz $\$ \$ 80-86$ IRL Act 2010. Zob. także B. E. Spierin, The succession..., dz. cyt., s. 315.

108 Por. $\$ 112$ IRL Act 1965. Zob. B. E. Spierin, The succession..., dz. cyt., s. 124; M. A. Zachariasiewicz, Zachowek..., dz. cyt., s. 192. W razie gdyby spadkodawca pozostawił dzieci, udział przysługujący małżonkowi wynosi jedną trzecią spadku; w braku dzieci natomiast udział ten odpowiada połowie spadku. Zob. $\$ \$ 111$ i 111A IRL Act 1965.

109 Zob. $\$ 109(2)$ IRL Act 1965 . Wedle prawa irlandzkiego na poczet roszczenia małżonka (i odpowiednio: partnera cywilnego) zalicza się świadczenia spełnione na jego rzecz przez spadkodawcę, które nie polegały jedynie na łożeniu na utrzymanie uprawnionego ( $\$ 116$ IRL Act 1965). W zakresie znanej w prawie szkockim instytucji election zob. $\$ 115$ IRL Act 1965. Por. także przyp. 108.

110 Por. szerzej na temat przesłanek roszczenia: $\$ 18$ Family Law (Divorce) Act 1996, no. 33 ze zm.

111 W razie spełnienia określonych przesłanek uprawniony jest także były konkubent.

Por. szerzej $\$ \$ 172(4)$ i 194 IRL Act 2010.

112 Zob. $\$ 117$ IRL Act 1965. 
mogą natomiast wystąpić na drogę sądową w celu uzyskania świadczenia ze spadku w wysokości, jaką sąd uzna za właściwą w świetle ogółu okoliczności, a zwłaszcza przysporzeń otrzymanych za życia spadkodawcy lub w spadku ${ }^{113}$. Ochrona ta odbywa się zatem w sposób charakterystyczny dla modelu dyskrecjonalnej władzy sądowej, co uzasadnia kwalifikację irlandzkiego uregulowania jako pośredniego pomiędzy obydwoma modelami skrajnymi ${ }^{114}$.

Model dyskrecjonalny nie znalazł wreszcie wyrazu w prawie amerykańskim ${ }^{115}$. Wedle unormowań stanowych ochrona przed pozbawieniem korzyści ze spadku polega na ogół na przyznaniu małżonkowi ${ }^{116}$

113 W przypadku małżonka rozwiedzionego i konkubenta zasądzone świadczenie, wraz z ewentualnymi alimentami przyznanymi uprzednio od spadkodawcy, nie może być jednak wyższe niż to, co uprawniony uzyskałby ze spadku, gdy bezpośrednio przed śmiercią spadkodawcy był jego małżonkiem lub partnerem cywilnym. Zob. $\$ 18(4)$ Family Law (Divorce) Act 1996, no. 33 ze zm. oraz $\$ \$ 172(5)$ i (7) IRL Act 2010.

114 Odmiennie niż w prawie szkockim, w ramach unormowań irlandzkich ograniczono mechanizm ochronny do przypadków dziedziczenia testamentowego. Tak: $\$$ 109(1) IRL Act 1965. Ustawodawca irlandzki dostrzegł natomiast niebezpieczeństwo osłabienia omawianego mechanizmu poprzez działania samego spadkodawcy, ukierunkowane na zubożenie spadku w drodze nieodpłatnych rozporządzeń inter vivos lub mortis causa poza porządkiem dziedziczenia. W myśl $\$ 121$ IRL Act 1965 sąd może uznać przedmiot takiego rozporządzenia za część spadku na potrzeby unormowania ochronnego. Nie dotyczy to jednak darowizn dokonanych na wcześniej niż trzy lata przed śmiercią spadkodawcy. Analogicznego rozwiązania brak natomiast w prawie szkockim. Konsekwentnie przeciwna jest mu szkocka komisja legislacyjna, powołująca się na brak zapotrzebowania na tego typu instytucję. Zob. Scottish Law Commission, Report no. 124..., dz. cyt., s. 36-38; Scottish Law Commission, Report no. 215 .., dz. cyt., s. 215.

115 Choć zyskał sobie zwolenników w literaturze. Zob. np. W. M. McGovern Jr., S. F. Kurtz, Wills, trust and estates, St. Paul 2004, s. 126-127 (i przywołana tam literatura).

116 W kwestii sytuacji prawnej małżonków i partnerów spadkodawcy por. także przyp. 38 . 
tzw. udziału fakultatywnego (elective share) ${ }^{117}$. Stanowi on ustawowo określoną część spadku ${ }^{118}$, która przysługuje małżonkowi niezależnie

117 Określanego czasem również jako forces share (dosł. udział przymusowy) czy statutory share. Por. szerzej: The American Law Institute, Restatement of the law (third). Property. Wills and other donative transfers, vol. 2, St. Paul 1999, s. $207 n$. Konstrukcję tę, choć w zmodyfikowanej postaci, przyjęto również w $\$ 2-202 n$ Uniform Probate Code, opracowanego przez National Conference of Commissioners on Uniform State Laws w 1969 roku, a następnie kilkukrotnie znowelizowanego [dalej: UPC]. UPC nie ma charakteru prawnie wiążącego, a jego obowiązywanie uzależnione jest od uchwalenia jego postanowień w poszczególnych stanach USA. Jego wpływ na treść prawa stanowionego w USA jest jednak znaczny (na jego rozwiązaniach w mniejszym lub większym zakresie wzoruje się blisko dwie piąte stanów USA). Por. szerzej na ten temat: B. Kucia, Forma testamentu w prawie amerykańskim, „Kwartalnik Prawa Prywatnego” (2012) z. 2, s. 422-423. Zob. treść UPC: National Conference of Commissioners on Uniform State Laws, Uniform Probate Code (1969), Chicago 2013. Na odmiennych założeniach oparto natomiast unormowanie Georgii, w którym ograniczenia swobody testowania ukształtowano wyjątkowo wąsko, przyznając małżonkowi i małoletnim dzieciom spadkodawcy ze spadku jedynie środki potrzebne do rocznego utrzymania po śmierci spadkodawcy (tzw. year's support). Zob. \$53-3-1 Georgia Code, Laws 1996, p. 504

$118 \mathrm{Na}$ sytuację prawną małżonka wpływają zarówno wielkość przysługującego mu udziału (najczęściej ułamkowego), jak i majątek, do którego udział ten ma być odniesiony. Zachodzi w tej mierze znaczne zróżnicowanie przyjętych rozwiązań. Tytułem przykładu, prawo Illinois przyznaje małżonkowi spadkodawcy udział odpowiadający jednej drugiej spadku; udział ten wynosi jednak jedną trzecią, jeśli spadkodawca pozostawił zstępnych ( $\$ 755$ ILCS 5/2-8 Illinois Compiled Statutes Annotated, P.A. 79-328). Wedle prawa Tennessee na wysokość udziału małżonka wpływa natomiast czas trwania małżeństwa ze spadkodawcą ( $\$ 31-$ 4-101 Tennessee Code, 1977 Pub.Acts, c. 25 ze zm.). Podobnie na tle $\$ 2-203$ (b) Uniform Probate Code. Udział małżonka na ogół odnosi się do spadku pozostałego po spłacie długów spadkowych. Zarówno w orzecznictwie, jak i w ustawodawstwie niektórych stanów dostrzega się ponadto potrzebę rozszerzenia pojęcia spadku i doliczenia do niego darowizn dokonanych przez spadkodawcę i przedmiotów jego dyspozycji mortis causa, które odniosły skutek poza porządkiem dziedziczenia. Zob. np. orzeczenie Sądu Apelacyjnego Nowego Jorku w sprawie Newman v. Dore, 1937, 9 N.E.2d 966. Zob. także $\$ 474.150$ Missouri Revised Statutes (L.1955, p. 385 ze zm.) i \$ 31-1-105 Tennessee Code, jak również $\$ 2-203$ i $\$ 2-205$ UPC. Por. szerzej E. Clark et al., Cases and materials..., dz. cyt., 
od odmiennych rozrządzeń testamentowych spadkodawcy ${ }^{119}$. Instytucja ta wyparła w ustawodawstwie stosowane wcześniej konstrukcje wiana (dower) i posagu (curtesy), obowiązujące obecnie w nielicznych unormowaniach stanowych ${ }^{120}$. Z przedstawionych mechanizmów nie korzystają natomiast w zasadzie porządki stanowe, w których stosunki majątkowe małżeńskie mogą być poddane reżimowi wspólności majątkowej ${ }^{121}$. Cechą charakterystyczną unormowań amerykańskich

s. 142-155. Odmienny sposób wyliczenia elective share przewiduje natomiast Uniform Probate Code, który wymaga uwzględnienia również majątku małżonka spadkodawcy i dokonanych przez niego dyspozycji, które w razie jego śmierci odniosłyby skutek poza porządkiem dziedziczenia. Na tym rozwiązaniu wzorują się m.in. unormowania stanów: Kansas (\$59-6a,201n Kansas Statutes, Laws 1994, c. 132 ze zm.), Montany ( $\$ 72-2-221 n$ Montana Code, Laws 1993, c. 494 ze zm.) i Minnesoty ( $\$ 524.2-201$ i n. Minnesota Statutes, Laws 1994, c. 472 ze zm.).

119 Wedle niektórych rozwiązań stanowych małżonek powołany do spadku na mocy testamentu powinien wybrać pomiędzy elective share a spadkobraniem testamentowym (tzw. election). Tego rodzaju rozwiązanie nie obowiązuje natomiast w unormowaniach wzorowanych na Uniform Probate Code, ponieważ udział spadkowy przypadający mu z mocy testamentu, ustawy i niektóre przedmioty uzyskane od spadkodawcy poza porządkiem dziedziczenia podlegają zaliczeniu na poczet elective share. Por. W. M. McGovern Jr., S. F. Kurtz, Wills..., dz. cyt., s. 153.

120 Instytucje dower i curtesy ukształtowano w prawie precedensowym, wedle którego w ramach dower przysługiwało wdowie dożywotnie prawo do jednej trzeciej części nieruchomości (real property) stanowiących własność męża w czasie trwania małżeństwa. Podobne uprawnienie przysługiwało wdowcowi w odniesieniu do wszystkich nieruchomości zmarłej żony, jednakże tylko w razie, gdyby małżonkowie mieli dzieci. Wspomniane instytucje utrzymano m.in. w prawie Kentucky ( $\$ 392.020$ Kentucky Statutes, 1956 c 117 ze zm.) i Ohio ( $\$ 2103.02$ Ohio Revised Code, 1953 H 1 ze zm.), choć niejednokrotnie w zmienionej postaci, co przejawia się zwłaszcza w ujednoliceniu sytuacji uprawnionych. Zob. np. E. Clark et al., Cases and materials..., dz. cyt., s. 139; W. M. McGovern Jr., S. F. Kurtz, Wills..., dz. cyt., s. 147-148; The American Law Institute, Restatement..., dz. cyt., s. 209.

121 Tak w blisko piątej części stanów UsA. Zob. np. prawo Arizony (\$25-211 Arizona Revised Statutes, 1973, Ch. 172 ze zm.), Kalifornii ( $\$ 7601992$ Cal. Legis. Serv. Ch. 162, A.B. 2650 , ze zm.), Newady ( $\$ 123.220$ Nevada Revised Statutes, Laws 
jest także to, że dzieci spadkodawcy podlegają zazwyczaj szczątkowej ochronie w ramach tzw. allowances ${ }^{122}$, które jednak przysługują także małżonkowi spadkodawcy ${ }^{123}$.

1975, p. 560 ze zm.), Nowego Meksyku ( $\$ 40-3-2$ New Mexico Statutes, Laws 1907 , c. 37 ze zm.). W stanach tych za wystarczającą ochronę małżonka uważa się ustrój wspólności majątkowej małżeńskiej (tzw. community property system). W niektórych porządkach prawnych wprowadzono jednak instytucję elective share w odniesieniu do tej części spadku, którą spadkodawca nabył w czasie, gdy zamieszkiwał poza stanem, w którym obowiązuje community property system. Tak np. w prawie Idaho ( $\$ 15-2-201$ Idaho Code, S.L. 1972, c. 201 ze zm.). Zob. szerzej: E. Clark et al., Cases and materials..., dz. cyt., s. 133 oraz s. 168n.; The American Law Institute, Restatement..., dz. cyt., s. 207n.

122 Wspomniane allowances (dosłownie: zasiłki, dodatki) na ogół korzystają z pierwszeństwa zaspokojenia przed długami spadkowymi, jak również, często, przed odmiennymi dyspozycjami testamentowymi. Por. np. E. Clark et al., Cases and materials..., dz. cyt., s. 135; W. M. McGovern Jr., S. F. Kurtz, Wills..., dz. cyt., s. 136-139. Tytułem przykładu Uniform Probate Code przewiduje: tzw. homestead allowance o wartości 22,5 tys. USD, tzw. exempt property o wartości 15 tys. USD (który w pierwszej kolejności powinien zostać zaspokojony z przedmiotów urządzenia domowego i użytku osobistego spadkodawcy, w tym także samochodów), jak również tzw. family allowance w rozsądnej kwocie pieniężnej potrzebnej do utrzymania w trakcie postępowania spadkowego, jednakże nie dłużej niż przez rok. W ramach family allowance Uniform Probate Code wykorzystuje więc konstrukcję charakterystyczną dla modelu dyskrecjonalnego. Wymienione uprawnienia przysługują niezależnie od udziału spadkowego uprawnionego (a w przypadku małżonka dodatkowo obok jego udziału fakultatywnego). Wedle UPC uprawnionym jest małżonek. Wraz z nim uprawnione do family allowance są dzieci spadkodawcy, które pozostawały na jego utrzymaniu. Pozostałe uprawnienia dodatkowe przysługują dzieciom jedynie w razie, gdyby spadkodawca nie pozostawił małżonka, z tym ograniczeniem, że homestead allowance przypada jedynie dzieciom małoletnim lub pozostającym na utrzymaniu spadkodawcy. Por. szerzej: $\$ 2-402$ do $\$ 2-405$ U PC. Por. także np. prawo Ohio ( $\$ 2106.13$ Ohio Revised Code, 1990 H 346) i Maryland (\$ 3-201 Maryland Estates and Trusts Code, 1974, c. 11 ze zm.).

123 Charakterystyczna dla prawa amerykańskiego jest także ochrona małżonka i dzieci spadkodawcy przez przyznanie im określonych udziałów w spadku, w razie gdyby spadkodawca w sposób niezamierzony nie ujął ich w testamencie (tzw. omitted heirs). Por. szerzej np. E. Clark et al., Cases and materials..., dz. cyt., s. 178 n. Zob. także np. $\$ \$ 2-301$ i 2-302 Uniform Probate Code. 


\section{Podsumowanie}

W systemach common law, podobnie jak w prawie polskim, dostrzega się potrzebę ochrony osób najbliższych spadkodawcy. Na kształt tej regulacji wpływa jednak istotnie przywiązanie do zasady swobody testowania, a także rozumienie pojęcia rodziny w poszczególnych systemach prawnych.

O poziomie ochrony bliskich spadkodawcy w danym przypadku decydują przy tym nie tylko unormowania prawa spadkowego w tym przedmiocie, lecz także instytucje prawa rodzinnego, a zwłaszcza te, które poświęcono małżeńskim ustrojom majątkowym. Ocena tego poziomu powinna zatem stanowić konsekwencję analizy unormowań prawnorodzinnych.

W licznych porządkach common law krąg osób bliskich spadkodawcy, które podlegają ochronie, jest stosunkowo wąski (tak np. w prawie amerykańskim), co nie zawsze jest aprobowane przez przedstawicieli nauki. W niektórych systemach spotyka się natomiast obszerne katalogi osób chronionych. Choć zakres personalny tych katalogów wydaje się szerszy niż w prawie polskim (art. 991 k.c.), to jednak nie zawsze wrażenie to odpowiada rzeczywistemu stanowi rzeczy. Trzeba bowiem zaznaczyć, że rodzice, wnukowie czy dalsi zstępni testatora są wedle prawa polskiego, w odpowiedniej kolejności, uprawnieni do zachowku, nawet jeśli nie pozostawali na utrzymaniu spadkodawcy w chwili jego śmierci, co nie zawsze stanowi regułę w unormowaniach krajów common law.

Nie zawsze też rozbudowany katalog osób uprawnionych gwarantuje ich należytą ochronę, co jest dostrzegalne zarówno w systemach prawnych, w których wprowadza się hierarchę uprawnionych (osoba zaliczana do kategorii dalszej może w ogóle nie uzyskać uprawnienia), jak i w systemach, w których nie unormowano tego rodzaju reguł pierwszeństwa. Do tych ostatnich należą systemy oparte na modelu dyskrecjonalnym. Wpisany w ideę tego modelu brak hierarchii uprawnionych 
do uzyskania korzyści ze spadku może prowadzić do niepożądanych rezultatów w razie konkurencji roszczeń. Spadek jako masa majątkowa ma ograniczony rozmiar. Zbyt szeroki krąg uprawnionych w tej samej kolejności, choć niekoniecznie w tym samym zakresie, może skutkować zmniejszeniem korzyści uzyskanych przez poszczególne osoby. Stąd też istotna jest wnikliwa analiza ogółu okoliczności sprawy, która pozwoli nie tylko ocenić roszczenie osoby inicjującej postępowanie sądowe, lecz także dostrzec roszczenia pozostałych osób. Wedle filozofii leżącej u podstaw tego rozwiązania niepożądanym rezultatom ma zapobiegać obowiązek wszechstronnej oceny sprawy, przy uwzględnieniu licznych kryteriów dotyczących stosunków osobistych i majątkowych spadkodawcy, spadkobierców i uprawnionego.

Nie wydaje się zasadne wprowadzenie modelu dyskrecjonalnego do prawa polskiego, przeciw czemu przemawia nie tylko niedookreśloność kryteriów, lecz również zbyt daleko idąca kompetencja sądu do modyfikacji ostatniej woli testatora, jak również ustalonego sposobu działu spadku.

Uzależnienie uprawnienia do zachowku od tego, czy spadkodawca łożył bezpośrednio przed swoją śmiercią na utrzymanie uprawnionego, czy też poważnie przyczyniał się do jego utrzymania, jest natomiast postulatem co najmniej wartym rozważenia. Chodzi tu zarówno o przypadek dobrowolnych świadczeń spadkodawcy, jak i sytuację, w której był do tego zobowiązany wobec zaktualizowania obowiązku alimentacyjnego w okolicznościach konkretnego przypadku. Pozwoliłoby to powiązać jeszcze bardziej instytucję zachowku z jej alimentacyjnym wymiarem. Podobnie wart uwagi jest spotykany w niektórych systemach common law wymóg, aby określony uprawniony istotnie przyczynił się do utrzymania spadkodawcy. Różne są tu możliwe postaci omawianych przesłanek, począwszy od sztywnego wymogu ustawowego, a skończywszy na ujęciu w ramach ogólnej normy interpretacyjnej, która winna być uwzględniana przy ocenie roszczenia w świetle zasad 
współżycia społecznego. Należy wszakże pozytywnie ocenić obecne rozwiązanie ustawowe, które odnośne okoliczności pozwala oceniać w ramach zarzutu nadużycia prawa podmiotowego (art. 5 k.c.). Zapewnia to niezbędną elastyczność polskiego unormowania zachowku, choć wiele zależy tu od praktyki orzeczniczej, która zdaje się wąsko zakreślać znaczenie omawianej instytucji na tle prawa polskiego ${ }^{124}$.

W świetle doświadczeń krajów common law warto również rozważyć potrzebę ingerencji ustawowej w zakresie wpływu różnych znanych prawu polskiemu instytucji umożliwiających sukcesję syngularną w razie śmierci na sposób obliczenia zachowku.

\section{Summary}

Restrictions on the freedom to make a last will introduced in order to protect the situation of the loved ones. Some remarks about the selected common law systems

There is usually no unrestricted freedom to make a last will. The respective legal systems differ in level of protection granted to persons close to the testator, both in legal catalogues of persons protected, as well as in terms of the legal nature of the entitlement conferred. Moving to the common law country may (and often will) result in submission of the said restrictions to the law of the state, where the emigrant settled.

After recognizing that problem, the author considers issues of the conflict of laws relating to restrictions on the testamentary freedom. He takes into account the entry into force of the Eu Regulation No. 650/2012 on succession. Furthermore, the author analyzes different models of protection of loved ones of the testator against disinheritance. He perceives both the diversity of legal catalogues of the protected persons, as well as the mechanisms of protection, often far different from the solutions accepted in Continental Europe legislation. In summary, the author formulates the legislative proposals.

Keywords: will, common law, legal rights, heritage, heir, civil law

124 Zob. jednak M. A. Zachariasiewicz, Zachowek..., dz. cyt., s. 199-202. 